Volume 119

Issue 4 Dickinson Law Review - Volume 119,

2014-2015

3-1-2015

\title{
Judicial Review of the EEOC's Duty To Conciliate
}

Stephanie Greene

Christine Neylon O'Brien

Follow this and additional works at: https://ideas.dickinsonlaw.psu.edu/dlra

\section{Recommended Citation}

Stephanie Greene \& Christine N. O'Brien, Judicial Review of the EEOC's Duty To Conciliate, 119 DICK. L. REV. 837 (2015).

Available at: https://ideas.dickinsonlaw.psu.edu/dlra/vol119/iss4/3

This Article is brought to you for free and open access by the Law Reviews at Dickinson Law IDEAS. It has been accepted for inclusion in Dickinson Law Review by an authorized editor of Dickinson Law IDEAS. For more information, please contactlja10@psu.edu. 


\title{
Judicial Review of the EEOC's Duty To Conciliate
}

\section{Stephanie Greene* \& Christine Neylon O'Brien**}

\begin{abstract}
More than 50 years after the enactment of Title VII of the Civil Rights Act of 1964, federal courts remain unsettled on a variety of issues involving the Equal Employment Opportunity Commission's ("EEOC") pre-suit obligations. Title VII gives the EEOC the authority to enforce the statute's prohibition on discrimination in the workplace. Before filing suit against an employer, the EEOC must satisfy several pre-suit requirements, including an attempt to eliminate the unlawful practice "by informal methods of conference, conciliation, and persuasion." Courts disagree on the following: (1) whether the EEOC's conciliation efforts are subject to judicial review; (2) what the standard of judicial review should be; (3) what the remedy should be if a court finds the EEOC failed to fulfill its pre-suit obligations; and (4) whether the EEOC may bring suit on behalf of unidentified individuals under $\S 706$ of Title VII. In EEOC v. Mach Mining, $L L C$, the Court of Appeals for the Seventh Circuit was the first circuit court of appeals to find that conciliation efforts are a matter of agency discretion and are not subject to judicial review. Other courts have reviewed the conciliation process and have required that the EEOC demonstrate at least good faith efforts to conciliate. The U.S. Supreme Court granted Mach Mining's petition for certiorari, and rendered its decision on April 29, 2015, as this article went to press.
\end{abstract}

* Professor and Chair of Business Law, Carroll School of Management, Boston College; B.A. Princeton University; J.D. Boston College Law School; M.A. Boston College.

** Professor of Business Law, Carroll School of Management, Boston College; B.A. Boston College; J.D. Boston College Law School. 
The Court did not specifically adopt the approach recommended by any of the lower courts. Although it disagreed with the Seventh Circuit's conclusion that conciliation efforts are not reviewable, the Court's decision and reasoning were more consistent with arguments made by the Seventh Circuit than by other circuit courts of appeal. The Supreme Court found that Title VII calls for a "relatively barebones review" of the EEOC's efforts. To satisfy its pre-suit obligations, the Court stated, the EEOC must inform the employer of the specific allegation and identify which individuals or class of employees suffered from the alleged discrimination. The Commission must then engage in discussion with the employer to attempt to resolve the problem. The EEOC must present some evidence verifying its efforts to conciliate and a court may review an employer's contention that conciliation did not occur. A court's review of the conciliation efforts is limited to fact-finding on those issues, the Supreme Court stated. The Supreme Court's decision largely echoes the Seventh Circuit's concern that courts recognize the broad discretion that Title VII gives to the EEOC in resolving disputes, the importance of Title VII's confidentiality provision, and Title VII's overarching goal of eradicating discrimination in the workplace. The Court stated that the remedy for failure to conciliate is more conciliation and not dismissal on the merits.

\section{Table of Contents}

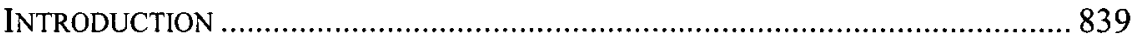

I. THE EEOC'S PRE-SUIT OBLIGATIONS ............................................... 842

II. EEOC V. MACH MINING: FAILURE TO CONCILIATE IS NOT SUBJECT TO JUDICIAL REVIEW

III. JUdiCIAL REVIEW AND THE STATUTORY SCHEME ............................. 850

A. The Deferential Standard ........................................................... 851

B. The More Stringent Standard ...................................................... 853

C. Controversies in Applying the More Stringent Standard ............. 857

D. Good Faith Standards's Inconsistency with an Informal and Confidential Conciliation Process ................................................ 860

IV. JUDICIAL REVIEW OF THE EEOC'S PRE-SUIT DUTIES REGARDING UNIDENTIFIED AGGRIEVED INDIVIDUALS IN $\S 706$ CLAIMS

A. Conciliation for Each Aggrieved Individual. .............................. 863

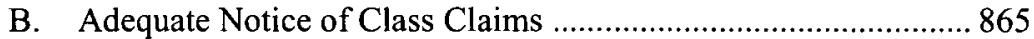

V. IMPACT OF THE SUPREME COURT'S DECISION: A NEW LANDSCAPE FOR EMPLOYERS AND EMPLOYEES

A. Resolution of the Merits and the EEOC's Discretion To Bring

Suit

B. The High Costs of Judicial Review and Minimal Benefits to Employers 


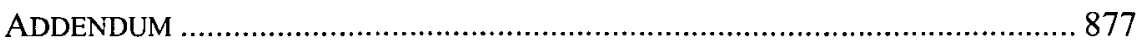

A. Manageable Judicial Review of Conciliation Efforts................... 877

B. Scope of Judicial Review - "Relatively Barebones" ................... 878

C. Conciliation Issues Resolved and Unresolved .............................. 880

\section{INTRODUCTION}

The Equal Employment Opportunity Commission ("EEOC" or "Commission") is charged with administering Title VII, which prohibits employment discrimination on the basis of race, color, religion, sex, or national origin. If the EEOC finds reasonable cause to sue an employer for an unlawful discriminatory practice, the statute requires that it "endeavor to eliminate the alleged unlawful employment practice by informal methods of conference, conciliation, and persuasion." EEOC and employers are currently locked in battle over how much effort the EEOC must exert to resolve a case before filing a discrimination suit under Title VII. Some employers and commentators suggest that the EEOC, motivated by the publicity of high-profile discrimination suits, has been overly aggressive in its litigation strategy. ${ }^{2}$ The EEOC should, they argue, be more diligent in its efforts to resolve charges of discrimination through voluntary conciliation. Moreover, to ensure that the EEOC gives employers an adequate opportunity to conciliate, courts should review the EEOC's efforts to determine whether the conciliation was conducted in good faith. Employers have even argued, with some success, that if the EEOC fails to conciliate in good faith, courts should dismiss the case. The EEOC concedes that it has a duty to conciliate before filing suit, ${ }^{3}$ and Title VII makes clear that conciliation is the preferred method of resolving charges of discrimination. ${ }^{4}$ The EEOC maintains, however, that nothing in the statute suggests that courts should review the EEOC's pre-suit efforts to resolve discrimination charges; on the contrary, Title VII defines conciliation as an "informal"

1. 42 U.S.C. $\S \S 2000 \mathrm{e}-2,2000 \mathrm{e}-3,2000 \mathrm{e}-5$ (a) (2012).

2. See, e.g., EEOC v. Mach Mining, LLC, 738 F.3d 171, 179 (7th Cir. 2013), cert. granted, 134 S. Ct. 2872 (June 30, 2014) (No. 13-1019). Mach Mining argued that "judges must police the EEOC, lest it either abandon conciliation altogether or misuse it by advancing unrealistic and even extortionate settlement demands." Id. In EEOC v. Agro Distribution, LLC, 555 F.3d 462, 468 (5th Cir. 2009), the court found that the EEOC made "an insupportable demand for compensatory damages as a weapon to force settlement."

3. Brief for the Respondent at 9, Mach Mining, 738 F.3d 171 (No. 13-1019).

4. Brief for Petitioner at 15, Mach Mining, 738 F.3d 171 (No. 13-1019) (citing Alexander v. Gardner-Denver Co., 415 U.S. 36, 44 (1974)) (noting "cooperation and voluntary compliance" as the preferred means of achieving equal employment opportunity). 
process and invests the EEOC with substantial discretion to determine when to accept or reject offers to settle and when to file suit. ${ }^{5}$ While most circuit courts of appeals have assumed that some judicial review of the conciliation process is appropriate, the Court of Appeals for the Seventh Circuit concluded that courts should not review the conciliation process. In EEOC v. Mach Mining, $L L C$, ${ }^{6}$ the Seventh Circuit rightly placed the primary goal of Title VII--resolving discrimination issues in the workplace-over the delays and distractions that result from the defense that employers have manufactured - failure to conciliate. ${ }^{7}$

In Mach Mining, the defendant-employer argued that the EEOC's failure to conciliate was an affirmative defense to charges of sex discrimination. ${ }^{8}$ In a bold decision that parts ways with decisions by other circuit courts of appeals, the Seventh Circuit held that the EEOC's conciliation efforts are a matter of agency discretion and are not subject to judicial review. ${ }^{9}$ Courts in other circuits have reviewed the conciliation process without specifically addressing the issue of whether Title VII allows such review. ${ }^{10}$ These courts have required that the EEOC demonstrate at least a good faith effort to conciliate.

While the most significant split is between the Seventh Circuit and circuits that have recognized some level of judicial review of conciliation efforts, other substantial differences exist among the circuits. Notably, the circuits disagree on the scope of litigation when conciliation fails, as well as the remedy a court should fashion if it finds the EEOC failed to conciliate in good faith. ${ }^{11}$ Some courts have dismissed the EEOC's suit or granted summary judgment to the employer upon finding that the EEOC did not conciliate in good faith. ${ }^{12}$ Other courts have found that

5. Brief for the Respondent, supra note 3, at 9-31.

6. EEOC v. Mach Mining, LLC, 738 F.3d 171, 171-184 (7th Cir. 2013), cert. granted, 134 S. Ct. 2872 (June 30, 2014) (No. 13- 1019).

7. Id. at 171 .

8. Id. at $171-72$.

9. Id. at 172 .

10. See infra Part III.

11. See infra Part IV.

12. See EEOC v. Peoplemark, Inc., 732 F. 3d 584, 621 (6th Cir. 2013); EEOC v. CRST Van Expedited, Inc., 679 F.3d 657, 664 (8th Cir. 2012); EEOC v. Agro Distribution, LLC, 555 F.3d 462, 469-70 (5th Cir. 2009); EEOC v. Asplundh Tree Expert Co., 340 F.3d 1256, 1261 (11 th Cir. 2003); EEOC v. Original Honeybaked Ham Co. of Ga., 918 F. Supp. 2d 1171, 1176 (D. Colo. 2013); EEOC v. Bloomberg L.P. (Bloomberg III), 778 F. Supp. 2d 458, 462 (S.D.N.Y. 2011). Attorneys from Seyfarth Shaw LLP maintain that the EEOC has become increasingly aggressive in its efforts. "Especially troubling," according to the firm, "are instances where the EEOC has rushed to file high-profile lawsuits that splash allegations of systemic discrimination across headlines, only to have its claims dismissed altogether or whittled down to a single claimant." Christopher J. Degroff, Reema Kapur \& Gerald A. Maatman, Jr., The Top 5 Most Intriguing Decisions in EEOC Cases of 2013 (and a Pre-Publication Preview of 
the better remedy is to stay the case to provide additional time for conciliation. $^{13}$

The EEOC's duty to conciliate raises additional questions when the EEOC brings claims under $\S 706^{14}$ of Title VII on behalf of unidentified victims. Courts have reached different conclusions about the extent of the EEOC's duty in -such cases. ${ }^{15}$ Some courts have found that the employer must have the opportunity to conciliate claims for each aggrieved individual. $^{16}$ Other courts have found that the EEOC need only give the employer adequate notice of the nature of the "class claims." 17 This issue is particularly important given the EEOC's emphasis on systemic discrimination and the U.S. Supreme Court's recent decision in Wal-Mart Stores $v$. Dukes, ${ }^{18}$ a decision that makes it more difficult to bring class action suits. ${ }^{19}$ Section 706 allows the EEOC to bring claims alleging a pattern or practice of discrimination, as well as claims for individual relief, without the strictures of Rule $23^{20}$ class certification. $^{21}$ While the Supreme Court did not address whether the EEOC must provide an opportunity for conciliation on each aggrieved individual before filing suit, its decision regarding judicial review of conciliation efforts will have a substantial impact on this issue. The actual question presented to the Court is: "[w]hether and to what extent may a court enforce the EEOC's mandatory duty to conciliate discrimination claims before filing suit.",22

This Article considers how courts should interpret the EEOC's duty to conciliate and the implications of the Supreme Court's decision in Mach Mining. The Article focuses primarily on cases arising under Title VII, but some cases arising under other statutes administered by the EEOC are relevant, because the administrative process is the same for

Our Annual EEOC Litigation Report), SEYFarTh Shaw (Dec. 31, 2013), http://www.seyfarth.com/publications/3794.

13. See EEOC v. Zia Co., 582 F.2d 527, 535 (10th Cir. 1978); EEOC v. Bass Pro Outdoor World, LLC, 1 F. Supp. 3d 647, 671 (S.D. Tex. 2014); EEOC v. Evans Fruit Co., 872 F. Supp. 2d 1107, 1115-16 (E.D. Wash. 2012).

14. 42 U.S.C. $\$ 2000 \mathrm{e}-5$ (2012).

15. See infra Part IV.

16. See infra Part IV.A.

17. See infra Part IV.B.

18. Wal-Mart Stores, Inc. v. Dukes, 131 S. Ct. 2541, 2541-67 (2011).

19. Id. at 2556-57 (holding that courts should consider dissimilarities to determine whether there is a common question for Rule 23 purposes and that claims for monetary relief may not be certified if the monetary relief is not incidental to the injunctive or declaratory relief).

20. FED. R. CIV. P. 23.

21. See Gen. Tel. Co. of the Nw. v. EEOC, 446 U.S. 318, 320 (1980).

22. Question Presented Report, Mach Mining, LLC v. EEOC, 738 F.3d 171 (7th Cir. 2013), cert. granted, 134 S. Ct. 2872 (June 30, 2014) (No. 13-1019), available at http://www.supremecourt.gov/qp/13-01019qp.pdf. 
the Americans with Disabilities Act ("ADA") 23 and the Age Discrimination in Employment Act ("ADEA"). ${ }^{24}$ Part I will introduce the specifics of the EEOC's pre-suit obligations. Part II will summarize the court's decision in Mach Mining. Part III will then identify the key differences among the circuit courts of appeals in addressing judicial review of conciliation efforts. This Part will expand on the Seventh Circuit's conclusion that in reviewing conciliation efforts, courts intrude on the informality of the process and the agency discretion that the statute calls for. Subsequently, Part IV will summarize the different approaches courts have taken in cases where the EEOC includes unidentified individuals as aggrieved parties in a lawsuit. Part V will maintain that courts should follow the Seventh Circuit's approach, which holds that the EEOC satisfies its statutory duty to conciliate by pleading that it has complied with the obligation. Part V will also support the EEOC's right to bring claims on behalf of unidentified parties because this practice allows the EEOC to more effectively address systemic discrimination. Finally, Part VI will conclude that judicial evaluation of conciliation efforts creates an unwarranted hurdle to the resolution of discrimination claims and interferes with the EEOC's ability to resolve claims of systemic discrimination. An Addendum outlines the U.S. Supreme Court's recent decision in Mach Mining and the extent to which it resolves issues regarding the EEOC's duty to conciliate.

\section{THE EEOC'S PRE-SUIT OBLIGATIONS}

When Title VII was enacted as part of the Civil Rights Act of $1964,{ }^{25}$ the EEOC's role was limited to addressing unlawful employment practices through "informal methods of conference, conciliation, and persuasion." 26 Congress aimed to encourage employers to comply voluntarily with Title VII. ${ }^{27}$ In 1972, recognizing that its hope for employers' voluntary compliance was "overly optimistic," Congress expanded the EEOC's enforcement powers by authorizing the agency to bring a civil action in federal district court against private employers

23. 42 U.S.C. $\$ \$ 12101-12213(2012)$.

24. 29 U.S.C. $\$ \$ 621-634$ (2012).

25. Civil Rights Act of 1964, Pub. L. No. 88-352, $\S \S 701-716,78$ Stat. 241, 253266 (codified as amended at 42 U.S.C. $\$ \S 2000 \mathrm{e}$ to $2000 \mathrm{e}-15$ ).

26. Civil Rights Act $\S 706$ (a) (codified as amended at 42 U.S.C. $\S 2000 \mathrm{e}-5(\mathrm{a})$ ); see also Gen. Tel., 446 U.S. at 325; Occidental Life Ins. Co. of Cal. v. EEOC, 432 U.S. 355 , 358 (1977).

27. See Gen. Tel., 446 U.S. at 325-26 (discussing Title VIl's initial enactment in 1964 limiting EEOC authority to "informal methods of conference, conciliation, and persuasion" and 1972 amendments to $\S 706$ creating meaningful enforcement powers with a right of action against private employers). 
suspected of violating Title VII. ${ }^{28}$ Title VII, as amended, preserves an individual's right to pursue his or her action but also authorizes the EEOC to file suit on behalf of the individual or on its own initiative if it believes that an employer engaged in a pattern or practice of discrimination. $^{29}$

The EEOC resolves the majority of its cases through mediation. ${ }^{30}$ In some cases, however, the EEOC may opt to file suit, particularly if the suit is of the type identified as a top priority in the EEOC's Strategic Enforcement Plan ("SEP"). In the 2013-2016 SEP, the EEOC identified preventing systemic discrimination as one of its top priorities. ${ }^{31}$

28. Equal Employment Opportunity Act of 1972, Pub. L. No. 92-261, 86 Stat. 103 (codified as amended at 42 U.S.C. $\$ 2000 \mathrm{e}(2012)$ ).

29. 42 U.S.C. $\S 2000 \mathrm{e}-6(\mathrm{e})$. The Supreme Court has explained that the private right of action was retained so that individuals could escape from the administrative action if it was taking too long. See Occidental Life, 432 U.S. at 362-63. The EEOC may also file suit on behalf of an individual who chooses not to file charges due to fear of employer retaliation. See EEOC v. Shell Oil Co., 466 U.S. 54, 62 (1984).

30. See Strategic Enforcement Plan FY 2013-2016, U.S. EQUAL EMP'T OPPORTUNITY COMM'N 13, http://www.eeoc.gov/eeoc/plan/upload/sep.pdf (last visited Apr. 17, 2015) [hereinafter $S E P$ ]. In 2012, 11,380 charges went to mediation, and $76 \%$ of the cases were resolved through the mediation process. Id. Authority to negotiate settlements and conciliation agreements, issue no cause findings, and make determinations regarding reasonable cause in most cases are delegated to district directors under the agency's regulations. Id. at 20 (citing 29 C.F.R. $\S 1601$ (2014)). The General Counsel retains significant authority to commence or intervene in litigation with some oversight by the EEOC in cases where there is a significant expenditure or public controversy. Id. The General Counsel may delegate cases to regional attorneys for the purpose of litigation. Id. at 21; see also Kevin P. McGowan, EEOC Officials, Attorneys Discuss Priorities Under Agency's Strategic Enforcement Plan, [2014] Daily Lab. Rep. (BNA), No. 11, at C-1, C-2 (Jan. 16, 2014) (discussing the EEOC's SEP and EEOC General Counsel P. David Lopez noting its priority of eliminating discriminatory barriers to employment, and his opinion that issue of affirmative defense to pre-suit obligations remains important despite Mach Mining).

31. See SEP, supra note 30 , at 12 . The EEOC sets priority charge handling procedures and devotes greater resources to and focuses attention on the areas set as meritorious priority matters in the SEP. Id. The EEOC's national priorities include: (1) "Eliminating Barriers in Recruitment and Hiring" (regarding class-based practices that adversely impact protected groups); (2) "Protecting Immigrant, Migrant and Other Vulnerable Workers" (from, for example, disparate pay, job segregation, or harassment); (3) "Addressing Emerging and Developing Issues" (noting the aging of the workforce and other trends or events that impact employment practices such as disability accommodation, including pregnancy-related disability discrimination, and coverage of LGBT discrimination under Title VII sex discrimination); (4) "Enforcing Equal Pay Laws" (targeting compensation systems and practices that discriminate based upon gender through directed investigations and Commissioner charges); (5) "Preserving Access to the Legal System" (targeting policies and practices that inhibit exercise of rights or impede EEOC investigative and enforcement efforts including: retaliation, overly broad waivers, settlement procedures that bar filing EEOC charges, or providing information to EEOC, and failure to retain records); (6) "Preventing Harassment Through Systemic Enforcement and Targeted Outreach" (targeting systemic enforcement and outreach to educate against future violations). $I d$. at 9-10. 
According to the EEOC, systemic discrimination involves "a pattern or practice, policy, or class case where the alleged discrimination has a broad impact on an industry, profession, company or geographic area. ${ }^{, 32}$

Title VII identifies several pre-suit obligations for the EEOC. First, the EEOC must receive a charge of discrimination, filed by the aggrieved party or by a Commissioner of the EEOC, alleging an unlawful employment practice. ${ }^{33}$ The EEOC must then notify the employer of the charge and begin an investigation. ${ }^{34}$ If, after investigation, the EEOC determines that there is reasonable cause to believe that the charge is true, it "shall endeavor to eliminate any such alleged unlawful employment practice by informal methods of conference, conciliation, and persuasion. ${ }^{35}$ The statute specifies that the informal conciliation procedures are confidential, that subsequent proceedings may not use information from conciliation as evidence, and that a violation of the confidentiality provision involves criminal penalties. ${ }^{36}$ If the EEOC is unable to reach a conciliation agreement "acceptable to the Commission, ${ }^{, 37}$ it may file a civil suit against the employer. ${ }^{38}$

The U.S. Supreme Court has emphasized that, although the EEOC has the authority to bring suits against employers reasonably suspected of violating Title VII, conciliation and voluntary compliance are the preferred methods of resolution. ${ }^{39}$ In Ford Motor Co. v. EEOC, ${ }^{40}$ the

32. Systemic Discrimination, U.S. EQUAL EMP'T OPPORTUNITY COMM'N, http://wwwl.eeoc.gov//eeoc/systemic/index.cfm (last visited Apr. 17, 2015). The EEOC provides the following examples of systemic practices:

Discriminatory barriers in recruitment and hiring; discriminatorily restricted access to management trainee programs and to high level jobs; exclusion of qualified women from traditionally male dominated fields of work; disability discrimination such as unlawful pre-employment inquiries; age discrimination in reductions in force and retirement benefits; and compliance with customer Id. preferences that result in discriminatory placement or assignments.

33. 42 U.S.C. $\S 2000 \mathrm{e}-5(\mathrm{~b})$ (2012); see Shell Oil, 466 U.S. at 67 (discussing substantive requirements for charges).

34. 42 U.S.C. $\S 2000 \mathrm{e}-5(\mathrm{~b})$.

35. Id.

36. Id. ("Any person who makes public information in violation of this subsection shall be fined not more than $\$ 1,000$ or imprisoned for not more than one year, or both.").

37. Id. $\S 2000 \mathrm{e}-5(\mathrm{f})(1)$.

38. Id ; see also Angela D. Morrison, Misconstruing Notice in EEOC Administrative Processing and Conciliation, 14 NEV. L.J. 785, 787-90 (2014) (reviewing the EEOC charge handling process and confidential conciliation process).

39. 42 U.S.C. $§ 2000 \mathrm{e}-5(\mathrm{f})(1)$ ("If . . the Commission has been unable to secure from the respondent a conciliation agreement acceptable to the Commission, the Commission may bring a civil action against . . .."); Alexander v. Gardner-Denver Co., 415 U.S. 36, 44 (1974) ("Cooperation and voluntary compliance were selected as the preferred means for achieving [Title VII's] goal."); see also Ricci v. DeStefano, 557 U.S. 557,581 (2009) ("[W]e have recognized as Congress's intent that 'voluntary compliance' 
Court recognized that "voluntary compliance" could end "discrimination far more quickly than could litigation proceeding at its often ponderous pace." ${ }^{, 41}$ In Occidental Life Insurance Co. v. EEOC, ${ }^{42}$ the Court, referring to Title VII's "integrated, multistep enforcement procedure,",43 stated that the EEOC is "required by law to refrain from commencing a civil action until it has discharged its administrative duties," which include "settling disputes, if possible, in an informal, noncoercive fashion." "44 Nevertheless, the Court has recognized that "once a charge is filed ... the EEOC is in command of the process ... [and] the master of its own case. ${ }^{35}$ In EEOC v. Waffle House, ${ }^{46}$ the Court stated that the statute clearly "confers on the agency the authority to evaluate the strength of the public interest at stake." ${ }^{47}$

The EEOC has not developed any regulations to define its duties to conciliate, except that it must "notify the respondent in writing" when it determines that conciliation will not resolve the charge. ${ }^{48}$ The EEOC maintains that its practice is to include an invitation to conciliate in its letter informing the employer that it has found reasonable cause to believe the employer engaged in an unlawful employment practice. ${ }^{49}$ According to the EEOC, these two documents, the reasonable cause letter with its invitation to negotiate and the notification that conciliation has failed, should serve as "bookends" that "show the Commission has attempted conciliation" without violating the confidentiality required by the statute. ${ }^{50}$

The EEOC's Quality Control Plan ("QCP") gives some indication of what criteria it considers for quality investigations and conciliations. ${ }^{51}$ According to the QCP, a quality investigation is one in which:

1. The Commission identifies the bases, issues, and relevant allegations of the alleged unlawful employment action in a charge.

be "the preferred means of achieving the objectives of Title VII."' (quoting Local No. 93, Int'l Ass'n of Firefighters v. City of Cleveland, 478 U.S. 501, 515 (1986)).

40. Ford Motor Co. v. EEOC, 458 U.S. 219 (1982).

41. Id. at 228 .

42. Occidental Life Ins. Co. of Cal. v. EEOC, 432 U.S. 355 (1977).

43. Id. at 359 .

44. Id. at 368 .

45. EEOC v. Waffle House, Inc., 534 U.S. 279, 291 (2002).

46. EEOC v. Waffle House, Inc., 534 U.S. 279 (2002).

47. Id. at 291 .

48. 29 C.F.R. § 1601.25 (2014).

49. See Brief for the Respondent, supra note 3, at 20.

50. Id. at 20-21.

51. See Quality Control Plan 2013 Draft Principles, U.S. EQUaL EMP'T OPPORTUNITY COMM'N, $\mathrm{http} / / \mathrm{www}$. eeoc.gov/eeoc/newsroom/release/quality_controlplan_2013.cfm (last visited Apr. 17, 2015). 
2. The Commission conducts an investigation consistent with its Priority Charge Handling Procedures (PCHP).

3. The Commission applies the law to the facts to determine if there is reasonable cause to believe that unlawful employment discrimination has occurred.

4. The Commission communicates with the Charging Party and the Respondent (or with their lawyers, if represented) to obtain sufficient information to make its determination.

The plan defines a quality conciliation as one in which:

1. The Commission seeks targeted, equitable relief.

2. The Commission informs the parties of the proposed categories of relief and how monetary terms were reached.

3. The Commission responds appropriately to reasonable offers made by the parties. ${ }^{52}$

The EEOC cautions that the QCP is intended for internal guidance only and is not to be used to determine whether investigations or conciliations were carried out in good faith. ${ }^{53}$ Nevertheless, some courts have used criteria similar to that specified in the QCP to assess investigation and conciliation efforts. ${ }^{54}$

To summarize, it is clear that conciliation is the preferred method of resolving discrimination charges. Title VII requires the EEOC to resolve charges through "informal methods of conference, conciliation, and persuasion." to the agency, it may bring a civil suit. ${ }^{56}$ The EEOC has not promulgated any regulations to further define its duties to conciliate. This information led the Seventh Circuit to conclude that nothing in Title VII or Supreme Court interpretations of the statute compels judicial review of conciliation efforts. ${ }^{57}$ Moreover, the Seventh Circuit found that the text of the statute and the overall objectives of Title VII weigh against judicial review. ${ }^{58}$

52. $I d$.

53. Id.

54. See discussion infra at Part III.B.

55. 42 U.S.C. $\S 2000 \mathrm{e}-5$ (b) (2012).

56. Id. $\S 2000 \mathrm{e}-5(\mathrm{f})(1)$.

57. EEOC v. Mach Mining, LLC, 738 F.3d 171, 172 (7th Cir. 2013), cert. granted, 134 S. Ct. 2872 (June 30, 2014) (No. 13-1019).

58. Id. at $174-80$. 


\section{EEOC $V$. MACH MINING: FAILURE To CONCILIATE Is NOT SUBJECT TO JUDICIAL REVIEW}

Brooke Petkas was truly a coal miner's daughter; her father, grandfathers, and great-grandfathers were all coal miners. ${ }^{59}$ Petkas had worked in mines in Southern Illinois, Indiana, and Pennsylvania since 2003. ${ }^{60}$ In 2006, she applied to work for Mach Mining when the company began operations near her hometown in Illinois. ${ }^{61}$ Petkas stated that she sent several resumes to Mach Mining but never got an interview. ${ }^{62}$

In 2008, Petkas filed a complaint with the EEOC, alleging that Mach Mining failed to hire her because of her sex..$^{63}$ The mine employed 130 miners, all men. ${ }^{64}$ Although the mine was newly constructed, it had neither bathrooms nor changing facilities for women. ${ }^{65}$ After Petkas filed with the EEOC, the EEOC found that at least 60 women had experiences similar to that of Petkas. ${ }^{66}$ The EEOC found there was reasonable cause to believe that Mach Mining had discriminated against female job applicants at its mine near Johnston City, Illinois. ${ }^{67}$ In 2010, the EEOC began informal conciliation, but in September of 2011, it informed Mach Mining that the conciliation efforts were unsuccessful. ${ }^{68}$ As a result, the EEOC filed suit on behalf of Petkas and a class of female job applicants. ${ }^{69}$ Mach Mining maintained that the case should be dismissed because the EEOC failed to conciliate in good faith before filing suit. ${ }^{70}$ The EEOC moved for summary judgment on the failure to conciliate claim. $^{71}$

The Court of Appeals for the Seventh Circuit, granting summary judgment for the EEOC, found that an alleged failure to conciliate is not an affirmative defense to the merits of a discrimination suit. ${ }^{72}$ The court reasoned that the language of the statute, the lack of a meaningful

59. Becky Malkovich, Female Miner: 1 Never Got a Call, SOUTHERN (Oct. 1, 2011), http://thesouthern.com/news/local/female-miner-i-never-got-a-call/article_b51d1e58-

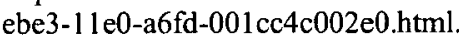

60. Id.

61. Id.

62. Id.

63. Id.

64. Malkovich, supra note 59.

65. Id.

66. Id.

67. EEOC v. Mach Mining, LLC, 738 F.3d 171, 173 (7th Cir. 2013), cert. granted, 134 S. Ct. 2872 (June 30, 2014) (No. 13-1019).

68. Id.

69. Id.

70. Id. at 172.

71. Id.

72. Mach Mining, 738 F.3d at 172. 
standard for courts to apply, and the overall statutory scheme weighed against allowing the affirmative defense. ${ }^{73}$ According to the court, allowing the defense would encourage employers to avoid liability for unlawful discrimination through "protracted and ultimately pointless litigation over whether the EEOC tried hard enough to settle."

The court first considered the text of Title VII. ${ }^{75}$ Not only did the court find no express language in the statute to support an affirmative defense, but it also found that language in the statute clearly demonstrates deference to the agency's decision-making powers. ${ }^{76}$ The court noted that the statute instructs the EEOC to "“endeavor to eliminate' discriminatory practices 'by informal methods"' and that the conciliation agreement had to be "'acceptable to the Commission.", 77 According to the court, "[i]t would be difficult for Congress to have packed more deference to agency decision-making into so few lines of text." 78

The court also found that the statute provided no workable legal standard for judicial review of the conciliation process, further supporting its position that the process is a matter of agency discretion. ${ }^{79}$ The court rejected Mach Mining's argument that it should use a good faith analysis similar to that employed under the National Labor Relations Act ("NLRA"). ${ }^{80}$ The court noted that the NLRA's requirement that employers and unions negotiate in good faith is an "explicit statutory command," while Title VII contains no similar requirement. ${ }^{81}$

Furthermore, the court noted that courts that have recognized an implied affirmative defense for failure to conciliate in good faith have attempted to distinguish between the conciliation process and the substance of the conciliation. ${ }^{82}$ The court found that a meaningful review of the process would necessarily involve information about the

73. Id.

74. Id.

75. Id. at $174-75$.

76. Id. at 174 .

77. Mach Mining, 738 F.3d at 174 (emphasis omitted) (quoting 42 U.S.C. $\S 2000 \mathrm{e}-$ 5(b), (f)(1) (2012)).

78. Id.

79. Id. at $175-78$.

80. National Labor Relations Act of 1935, Pub. L. No. 74-198, 49 Stat. 449 (codified as amended at 29 U.S.C. $\S \S 151-169$ (2012)); Mach Mining, 738 F.3d at 176.

81. Mach Mining, 738 F.3d at 176 (explaining that the NLRA outlines specific violations of the Act such that it is an unfair labor practice if either employers or unions fail to bargain in good faith); see 29 U.S.C. $\S 158$ (2012) (outlining employer and union unfair labor practices and the duty to bargain in good faith under $\S 8$ of the Act).

82. Mach Mining, 738 F.3d at 176-77 (citing EEOC v. Hibbing Taconite Co., 266 F.R.D. 260, 273 (D. Minn. 2009)). 
substance of the parties' positions, including the reasonableness of offers and the use of confidential and inadmissible evidence. ${ }^{83}$ Such review would necessarily undermine the EEOC's discretion in choosing whether or not to settle the case. ${ }^{84}$

The court found support for its position in decisions addressing challenges to agency actions under the Administrative Procedure Act ("APA") ${ }^{85}$ The court referred to Supreme Court decisions finding that there is no judicial review " if the statute is drawn so that a court would have no meaningful standard against which to judge the agency's exercise of discretion." "'86 The court found its decision consistent with these APA cases because "the statutory directive to attempt conciliation is so similar to those open-ended grants of authority that courts have found committed to agency discretion by law and thus not subject to judicial review under the APA." 87

The court concluded that recognizing an affirmative defense for failure to conciliate would undermine the informal conciliation process required by Title VII by turning the process into "endless disputes over whether the EEOC did enough before going to court. ${ }^{" 88}$ This result, according to the court, would conflict with the Supreme Court's interpretation that Congress intended "voluntary compliance [to] be the preferred means of achieving the objectives of Title VII." ${ }^{89}$ The court stated that in some cases, especially those in which the underlying claim of discrimination is strong, an employer may build its case around the EEOC's alleged failure to conciliate to escape liability, rather than engage in meaningful settlement discussions. ${ }^{90}$

The court found no merit to Mach Mining's contention that "judges must police the EEOC, lest it either abandon conciliation altogether or misuse it by advancing unrealistic and even extortionate settlement

83. Id. at 177

84. Id.

85. Administrative Procedure Act of 1946, Pub. L. No. 79-404, 60 Stat. 237 (codified as amended in scattered sections of 5 U.S.C.); Mach Mining, 738 F.3d at 177.

86. Mach Mining, 738 F.3d at 177 (quoting Webster v. Doe, 486 U.S. 592, 600 (1988)). The Mach Mining court found that even though there is a presumption of judicial review, its conclusion was consistent with Supreme Court decisions recognizing the " "presumption favoring judicial review of administrative action is just that-a presumption." Id. at 178 (quoting Block v. Cmty Nutrition Inst., 467 U.S. 340, 349 (1984)). The presumption may be overcome " whenever the congressional intent to preclude judicial review is fairly discernible in the statutory scheme." Id. (quoting Block, 467 U.S. at 351). Title VII, the court stated, provides no standards to indicate that Congress intended judicial review of the conciliation process. Id.

87. Id. at 177 .

88. Id. at 179 .

89. Id. at 178 (quoting Ricci v. DeStefano, 557 U.S. 557, 581 (2009)).

90. Id. at 179 . 
demands." $"$ The court cited statistical evidence to indicate that the EEOC uses its limited resources to bring suit in only a small percentage of cases. ${ }^{92}$ In 2012, the court noted, the EEOC "attempted conciliation in 4207 cases, was unsuccessful in 2616 , yet filed suit on the merits in just 122." .93

The court noted that the effect of an affirmative defense for failure to conciliate is more likely to encourage employers to strategically avoid settlement with the hope that the case will be dismissed altogether. ${ }^{94}$ Furthermore, the defense would do little to deter EEOC misconduct, according to the court, while potentially allowing meritorious cases of discrimination to go unaddressed. ${ }^{95}$ In short, the court found that dismissal of the case for "insufficient process" was "too final and drastic a remedy." 96 The court noted that the Supreme Court has articulated a clear standard that "'the remedy for a deficiency in a process is more process, not letting one party off the hook entirely.",97

The Seventh Circuit's decision is bold in contrast to approaches taken by other courts. The Seventh Circuit asserted, "[i]f the EEOC has pled on the face of its complaint that it has complied with all procedures required under Title VII and the relevant documents are facially sufficient, our review of those procedures is satisfied." 98 In its review of the Seventh Circuit's decision, the Supreme Court had to decide whether such facial compliance satisfied the EEOC's pre-suit obligations.

\section{JUDICIAL REVIEW AND THE STATUTORY SCHEME}

In deciding whether the EEOC's conciliation efforts are subject to judicial review, the Supreme Court had three models from which to choose. First, the Seventh Circuit asserted that courts should not review conciliation efforts. It maintained that the EEOC discharges its pre-suit obligations by stating that it has done so in its complaint and submitting documents that are facially sufficient. ${ }^{99}$ Second, three circuits have

91. Mach Mining, 738 F.3d at 179.

92. Id. at $\mathbf{1 8 0 .}$

93. Id. (citing All Statutes: FY 1997 Through FY 2012, U.S. EQUAL EMP'T OPPORTUNITY COMM'N, http://www.eeoc.gov/eeoc/statistics/enforcement/all.cfm (last visited Dec. 20, 2013); EEOC Litigation Statistics, FY 1997 Through FY 2012, U.S. EQUAL EMP' T OPPORTUNITY COMM'N, http://www.eeoc.gov/eeoc/statistics/enforcement/litigation.cfm (last visited Dec. 20, 2013)).

94. Id. at $183-84$.

95. Id. at 184 .

96. Mach Mining, 738 F.3d at 184.

97. Id. (citing Hamdi v. Rumsfeld, 542 U.S. 507, 533 (2004)).

98. Id. (internal citation omitted).

99. Id. 
concluded that the EEOC must demonstrate a good faith effort to conciliate. $^{100}$ This standard of review has been labeled the deferential standard of review. ${ }^{101}$ The Ninth Circuit has not yet adopted a view, but one district court within the circuit has indicated that it leans toward the deferential standard. ${ }^{102}$ Third, three circuits have followed a more stringent approach that uses a three-part inquiry to determine whether the EEOC acted in a reasonable manner in attempting to conciliate the charge. ${ }^{103}$ In applying either variation of a good faith standard, deferential or stringent, courts within these circuits have recognized the importance of the conciliation process as the means of achieving the statute's goal of "voluntary compliance," while also recognizing that Congress gave the EEOC broad discretion in how it goes about the process of conciliation. Parts III.A-B set forth the deferential and the more stringent standards of judicial review of conciliation efforts. Part III.C concludes that decisions employing either standard of review have been highly subjective, with courts assessing conciliation efforts with varying degrees of deference to the EEOC.

\section{A. The Deferential Standard}

The Fourth, Sixth, and Tenth Circuits require that the EEOC's conciliation efforts meet a minimal level of good faith. ${ }^{104}$ Courts have

100. See, e.g., EEOC v. Keco Indus., Inc., 748 F.2d 1097, 1102 (6th Cir. 1984); EEOC v. Radiator Specialty Co., 610 F.2d 178, 183 (4th Cir. 1979); EEOC v. Zia Co., 582 F.2d 527, 533 (10th Cir. 1978).

101. See Elizabeth Dunn, No Longer a Paper Tiger: The EEOC and Its Statutory Duty To Conciliate, 63 EMORY L.J. 455, 462 (2013) (categorizing the views of the Sixth and Tenth Circuits as the "deferential standard of review").

102. In EEOC v. Alia Corp., 8242 F. Supp. 2d 1243 (E.D. Cal. 2012), the court stated that, "district courts in this circuit have generally tilted toward the approach taken by the Sixth and Tenth circuits, affording the EEOC wide deference in discharging its duty to conciliate." Id. at 1255. In EEOC v. Swissport Fueling, Inc., 916 F. Supp. 2d 1005 (D. Ariz. 2013), the court stated that review of the EEOC's effort to fulfill its statutory duties is appropriate. $I d$. at 1025 (citing EEOC v. Pierce Packing Co., 669 F.2d 605, 608 (9th Cir. 1982)). The court found that "the EEOC's investigatory and conciliatory obligations, standing alone, may be immune from judicial review" but that "the Ninth Circuit has held that once the EEOC begins litigation, its investigation, determination, and conciliation are subject to judicial review as "jurisdictional conditions precedent to suit." Id. at 1035 (citing Pierce Packing, 669 F.2d at 608). In Swissport, the court took note of the circuit split on standards to evaluate conciliation efforts but did not adopt either standard, finding that the EEOC had not met its pre-suit obligations under either standard. Id. at 1037.

103. See, e.g., EEOC v. Agro Distrib., LLC, 555 F.3d 462, 467-69 (5th Cir. 2009); EEOC v. Asplundh Tree Expert Co., 340 F.3d 1256, 1259-61 (11th Cir. 2003); EEOC v. Johnson \& Higgins, Inc., 91 F.3d 1529, 1534-35 (2d Cir. 1996).

104. Keco, 748 F.2d at 1102; Radiator Specialty, 610 F.2d at 183; Zia Co., 582 F.2d at 533 . 
not provided any specifics on how to determine whether the EEOC fulfilled its duties in good faith, but it appears that under this standard, there is no scrutiny of how the process was conducted. For example, in EEOC v. Radiator Specialty Co., ${ }^{105}$ the Court of Appeals for the Fourth Circuit found that the law requires "no more than a good faith attempt at conciliation." "106 The court held that a good faith attempt was made when the EEOC sent a reasonable cause determination letter with an invitation to conciliate, discussed charges during a tour of the employer's plant, and suggested a meeting to discuss an agreement. ${ }^{107}$ Because the employer failed to respond to the EEOC's express overtures to conciliate, the EEOC was free to file suit, according to the court. ${ }^{108}$

Similarly, in EEOC v. Keco Industries, Inc., ${ }^{109}$ the Court of Appeals for the Sixth Circuit stated that "the EEOC must make a good faith effort to conciliate the claim. However, once the employer rejects the conciliation attempts, the EEOC is free to file suit under Title VII." 110 The district court had dismissed the suit on the grounds that the investigation was incomplete and the employer did not have a meaningful opportunity to conciliate. ${ }^{111}$ The determination of failure to conciliate was based on a magistrate's report indicating that "the EEOC conciliation attempts consisted solely of 'placing . . . boilerplate language regarding the class discrimination claim into the conciliation agreement." 112 The Sixth Circuit reversed, emphasizing that the district court "should only determine whether the EEOC made an attempt at conciliation" and that the "form and substance of those conciliations is within the discretion of the EEOC."113 In Serrano v. Cintas Corp.," a more recent decision, the Sixth Circuit reaffirmed its holding in Keco and stated that "the nature and extent of an EEOC investigation ... is a matter within the discretion of th[e] agency.",115 The court found that when an employer rejects the EEOC's offer to conciliate and the

105. EEOC v. Radiator Specialty Co., 610 F.2d 178 (4th Cir. 1979).

106. Id. at 183 .

107. Id.

108. Id.

109. EEOC v. Keco Indust., Inc., 748 F.2d 1097 (6th Cir. 1984).

110. Id. at 1102 .

111. See id. at 1099.

112. See id. at 1101 (alteration in original).

113. Id. at 1102 .

114. Serrano v. Cintas Corp., 699 F.3d 884 (6th Cir. 2012), cert. denied, 134 S. Ct. 92 (2013).

115. Id. at 904 (second alteration in original) (quoting Keco, 748 F.2d at 1100). 
proposed conciliation agreement, the "EEOC is under no duty to attempt further conciliation." 116

The Court of Appeals for the Tenth Circuit, in EEOC v. Zia Co., ${ }^{117}$ also held that the EEOC had a duty to conciliate in good faith. ${ }^{118}$ Because the law states that the EEOC "shall seek conciliation," the court noted that "it is inconceivable to us that good faith efforts are not - required." 119 In Zia, the alleged lack of good faith on the EEOC's part was based on the fact that the EEOC litigation officials, knowing that a conciliation agreement was imminent, acted improperly in not giving the parties more time to complete the agreement. ${ }^{120}$ The appropriate remedy, according to the court, was to give the parties more time to reach an agreement. ${ }^{121}$

The approach taken by these courts is not unlike the Seventh Circuit's approach in Mach Mining. Although these decisions do not go as far as the Seventh Circuit by expressly rejecting failure to conciliate as an affirmative defense, they steer clear of engaging in an inquiry into the substance of the negotiations. The courts in Radiator Specialty Co. and Keco were satisfied that some attempt to conciliate took place, remaining close to the Seventh Circuit's approach, which requires only that the EEOC's documents be "facially sufficient." 122 In Zia, although the court found that the EEOC did not exercise good faith, the court directed the parties to resume conciliation. ${ }^{123}$ This remedy is consistent with the Seventh Circuit's suggestion that a procedural wrong can be cured by "a short stay to allow the parties to pursue conciliation further." 24

\section{B. The More Stringent Standard}

Some circuit courts of appeals recognize a second standard of review, known as the "more stringent standard." The Second, Fifth, and

116. Id. at 905 (quoting Keco, 748 F.2d at 1101-02). The court noted that the company's three-year silence after the EEOC's proposal "can reasonably be interpreted as rejection," and thus, "the EEOC satisfied its administrative prerequisites to suit." Id.

117. EEOC v. Zia Co., 582 F.2d 527 (10th Cir. 1978).

118. Id. at 533 .

119. Id.

120. Id. at 534. The case involved unique circumstances. Zia, the private employer, was willing to sign a conciliation agreement with the EEOC, but, because a contractual agreement required the Atomic Energy Commission ("AEC") to satisfy any back pay agreements, Zia needed the AEC's approval. Id. at 530.

121. Id. at 534 .

122. EEOC v. Mach Mining, LLC, 738 F.3d 171, 184 (7th Cir. 2013), cert. granted, 134 S. Ct. 2872 (June 30, 2014) (No. 13-1019).

123. Zia, 582 F.2d at 533 . The court noted that it retained jurisdiction to make findings and orders without retrial and without creating statute of limitations problems on individual claims if further conciliation efforts failed. Id.

124. Mach Mining, 738 F.3d at 184. 
Eleventh Circuits have reviewed conciliation efforts under a good faith standard, aided by a three-part inquiry. ${ }^{125}$ The three-part inquiry was established by the Fifth Circuit in Marshall v. Sun Oil Co. (Delaware), ${ }^{126}$ a case involving age discrimination under the ADEA, which, like Title VII, requires efforts to conciliate before filing suit. ${ }^{127}$ The inquiry asks whether the government agency: (1) outlined to the employer its cause for believing the statute has been violated; (2) gave the employer a chance to comply voluntarily; and (3) responded in a reasonable and flexible manner to reasonable questions or offers by the respondent. ${ }^{128}$ Interestingly, the three-part inquiry corresponds closely to the internal guidelines of the EEOC's QCP. ${ }^{129}$ The third component of the inquiry, the requirement that the EEOC respond reasonably and flexibly to the employer, appears to be the critical inquiry and one that has raised considerable problems for the EEOC.

In EEOC v. Klingler Electric Corp., ${ }^{130}$ the Fifth Circuit stated that it is "appropriate . . . to inquire into the adequacy of the EEOC's efforts to conciliate."131 Adapting the three-part inquiry to Title VII, the court stated that "the fundamental question is the reasonableness and responsiveness of the EEOC's conduct under all the circumstances.", The court found that in this case it was necessary to make a "thorough inquiry into [the] relevant facts of the conciliation negotiations."133 The employer attempted to show that it had signed a conciliation agreement. $^{134}$ But the facts showed that the employer's purported acceptance of the agreement contained an alteration that was objectionable to the EEOC and the charging party. ${ }^{135}$ The Fifth Circuit

125. See EEOC v. Asplundh Tree Expert Co., 340 F.3d 1256, 1259 (11th Cir. 2003); EEOC v. Johnson \& Higgins, Inc., 91 F.3d 1529, 1534 (2d Cir. 1996); EEOC v. Klingler Electric Corp., 636 F.2d 104, 107 (5th Cir. Unit A Feb. 1981) (per curiam).

126. Marshall v. Sun Oil Co. (Del.), 605 F.2d 1331 (5th Cir. 1979).

127. The ADEA requires that before filing suit the Secretary seek voluntary compliance "through informal methods of conciliation, conference, and persuasion." 29 U.S.C. $\S 626(b)$ (2012). Sun Oil moved for summary judgment on the ground that the Secretary of Labor's attempts to conciliate charges of age discrimination were inadequate. Marshall, 605 F.2d at 1332.

128. Marshall, 605 F.2d at 1339.

129. See supra notes 51 and 52 and accompanying text.

130. EEOC v. Klingler Electric Corp., 636 F.2d 104 (5th Cir. Unit A Feb. 1981) (per curiam).

131. Id. at 107. The Fifth Circuit noted further that there is no requirement that the EEOC specifically aver in the pleadings that conciliation has failed; to the contrary, a general averment that conditions precedent to filing suit have been met is adequate. Id. at 106.

132. Id. at 107.

133. Id.

134. Id. at 106.

135. Klingler, 636 F.2d at 106. 
remanded for the trial court to inquire into the relevant facts regarding the materiality of the information the employer added to the conciliation agreement, the history of negotiations on that item, the nature of the EEOC's counter-proposal, and the employer's response. ${ }^{136}$

In EEOC v. Agro Distribution, L.L.C. ${ }^{137}$ however, the Fifth Circuit found that the EEOC did not attempt conciliation in good faith because it failed to respond in a reasonable and flexible manner to the reasonable attitudes of the employer. ${ }^{138}$ In Agro, the court looked closely at the behavior of the negotiating parties. It held that the EEOC did not attempt conciliation in good faith because it "abandoned its role as a neutral investigator" and made "an insupportable demand for compensatory damages as a weapon to force settlement." claimant's own deposition indicated that no violation of the ADA had occurred and no reasonable jury could conclude that the employer had denied the employee reasonable accommodation. ${ }^{140}$ The Fifth Circuit found that dismissal and an award of attorneys' fees were appropriate because the EEOC failed to act in good faith. ${ }^{141}$

In EEOC v. Asplundh Tree Expert Co. ${ }^{142}$ the Court of Appeals for the Eleventh Circuit also upheld the dismissal of a claim because the EEOC had failed to conciliate in good faith. ${ }^{143}$ For nearly three years, the EEOC investigated a claim of racial harassment and retaliation as well as pay disparity and concluded that there was reasonable cause to believe the allegations were true. ${ }^{144}$ The EEOC sent a conciliation agreement to the employer's general counsel giving the company 12 days to reply. ${ }^{145}$ The company's general counsel retained local counsel who contacted the EEOC, requesting additional time to conciliate. ${ }^{146}$ The EEOC did not respond and informed the employer that "further conciliation efforts would be futile or non-productive." 147 The court employed the same three-part test as the Fifth Circuit did in Klingler and

136. Id. at 107 .

137. EEOC v. Agro Distrib., LLC, 555 F. 3d 462 (5th Cir. 2009).

138. Id. at 468 .

139. Id. It should be noted that the EEOC does not conciliate until it has found reasonable cause, and once the EEOC has found such cause, it is no longer a "neutral investigator" but an agency seeking to eliminate discrimination. 29 C.F.R. $§ 1601.24$ (a) (2014).

140. Agro, 555 F.3d at 471.

141. Id. at 469 .

142. EEOC v. Asplundh Tree Expert Co., 340 F.3d 1256 (11 th Cir. 2003).

143. Id. at 1261. The court also upheld an award of attorneys' fees for the employer. Id.

144. Id. at 1258 .

145. Id.

146. Id.

147. Asplundh, 340 F.3d at 1258-59. 
emphasized "the reasonableness and responsiveness of the EEOC's conduct under all the circumstances." 148 The court found that the EEOC did not act in good faith and that its conduct "smacks more of coercion than of conciliation." 149 The court noted that the EEOC did not provide the employer with notice of a theory of liability, as the racial comments were made by an employee of another company; that the EEOC unreasonably denied a request to extend the conciliation period; and that the EEOC's proposed remedy was "impossible to perform." 150 Finding that the EEOC did not fulfill its statutory duty to attempt conciliation in good faith, the Eleventh Circuit upheld the district court's dismissal of the case and an award of attorneys' fees. ${ }^{151}$

The Court of Appeals for the Second Circuit also employs the threepart inquiry to assess good faith attempts to conciliate. In EEOC $v$. Johnson \& Higgins,${ }^{152}$ the court decided an age discrimination claim brought by the EEOC regarding a mandatory retirement policy for employees serving as directors. ${ }^{153}$ Johnson \& Higgins maintained that the EEOC did not satisfy its duty to conciliate before filing suit. ${ }^{154}$ The Second Circuit found that it was "entirely appropriate" for the EEOC to end conciliation efforts when the employer refused to provide the EEOC with information regarding salaries in order to negotiate damages. ${ }^{155}$ The court found that the EEOC had fulfilled its duty by issuing its letter of determination and inviting the employer to conciliate. ${ }^{156}$ Because the employer refused to cooperate on the grounds that its policy was not unlawful, the court concluded that "it was entirely appropriate for the EEOC to end conciliation efforts at that point and file suit ...."157

The Seventh Circuit rejected the approach used by the Second, Fifth, and Eleventh Circuits because it found that the approach necessarily required inquiry into the substantive nature of the EEOC's negotiations and consequently interfered with the confidentiality requirements of Title VII, as well as the agency's discretion to accept or

148. Id. at 1259 .

149. Id. at 1260 (quoting EEOC v. Pet, Inc., 612 F.2d 1001, 1002 (5th Cir. 1980)).

150. Id. The court stated that the remedy was "impossible to perform" because the EEOC required reinstatement and front pay for the employee when the project had ended three years earlier. Id.

151. Id. at 1261 .

152. EEOC v. Johnson \& Higgins, Inc., 91 F.3d 1529 (2d Cir. 1996).

153. Id. at 1531.

154. Id. at 1534 .

155. Id. at 1535 .

156. Id.

157. Johnson, 91 F.3d at 1535. 
reject settlements. ${ }^{158}$ Cases in the federal district courts, discussed next, further demonstrate that the more stringent standard of review opens the door to several problems highlighted by the Seventh Circuit in Mach Mining.

\section{Controversies in Applying the More Stringent Standard}

Recent decisions in which courts have used the three-part inquiry in assessing conciliation efforts demonstrate that outcomes vary depending upon a court's subjective assessment of the reasonableness of the requests and responses made during the conciliation process. In Mach Mining, the Seventh Circuit warned that when courts review conciliation efforts, they become enmeshed in trying to distinguish between the process and substance of the conciliation, interfering not only with the informality for which the statute explicitly calls but also with the confidentiality it mandates. ${ }^{159}$ Some courts have embraced a full inquiry into the parties' behavior and the details of their negotiations. ${ }^{160}$ Two recent federal district court cases from within the Second and Fifth Circuits demonstrate the difficulties associated with applying the more stringent standard of review.

In a series of recent decisions from within the Second Circuit, the U.S. District Court for the Southern District of New York dealt with charges brought by the EEOC against Bloomberg L.P., asserting claims of sex and pregnancy discrimination as well as retaliation under Title VII. $^{161}$ In EEOC v. Bloomberg L.P., ${ }^{162}$ the court considered claims related to sex and pregnancy discrimination and concluded that the EEOC had fulfilled its duty to conciliate. ${ }^{163}$ Applying the Second Circuit's rule articulated in Johnson \& Higgins, the court held that where a defendant refuses the agency's invitation to conciliate, the EEOC may

158. EEOC v. Mach Mining, LLC, 738 F.3d 171, 183 (7th Cir. 2013), cert. granted, 134 S. Ct. 2872 (June 30, 2014) (No. 13-1019).

159. Id. at 177.

160. See, e.g., EEOC v. Klingler Electric Corp., 636 F.2d 104, 107 (5th Cir. Unit A Feb. 1981) (per curiam) (stating it was necessary to make a "thorough inquiry into [the] relevant facts of the conciliation negotiations").

161. EEOC v. Bloomberg L.P. (Bloomberg II), 751 F. Supp. 2d 628, 630 (S.D.N.Y. 2010). In EEOC v. Bloomberg L.P. (Bloomberg I), No. 07 Civ. 8383 (LAP), 2010 U.S. Dist. LEXIS 92511 (S.D.N.Y., Aug. 31, 2010), the court ruled against excluding Bloomberg's expert witnesses. However, the court ruled in favor of denying the introduction of testimony and reports of the EEOC's experts on the basis of their minimal probative value regarding gender stereotyping and their tendency to prejudice the jury, in light of the unreliability of data and lack of relevance. Bloomberg I, 2010 U.S. Dist. LEXIS 92511, at *55-56.

162. EEOC v. Bloomberg L.P. (Bloomberg II), 751 F. Supp. 2 d 628 (S.D.N.Y. 2010 ).

163. Id. at 630,638 . 
proceed to litigation. ${ }^{164}$ The court noted that "when the parties' proposals and discussions are so divergent as to seem irreconcilable, the courts will not require the EEOC to conduct Sisyphean negotiations to meet its statutory mandate to conciliate." 165

In Bloomberg, however, the court found that the EEOC failed to conciliate the retaliation claims in good faith. ${ }^{166}$ During the course of negotiations, Bloomberg informed the EEOC that it looked forward to working with the agency to "achieve a resolution" while at the same time noting that it was "not in a position" to offer monetary relief. ${ }^{167}$ While the EEOC held out for a "reasonable" response on the monetary proposals, ${ }^{168}$ Bloomberg repeatedly sought more information regarding the claims in order to formulate a counterproposal. ${ }^{169}$ After five months of correspondence and an unproductive meeting, the EEOC sent a letter stating that the conciliation efforts were unsuccessful. ${ }^{170}$ The court found that the EEOC failed to "respond in a reasonable and flexible manner to the employer in conciliation."171 The court noted that the EEOC's proposal totaled over $\$ 41$ million and that Bloomberg's requests for more information about the charges and the basis for the agency's determination were reasonable. ${ }^{172}$ According to the court, the EEOC "stonewalled" Bloomberg's reasonable requests for information. ${ }^{173}$ The court found that the EEOC's failure to conciliate the retaliation claims should result in a dismissal rather than a stay of proceedings in light of the EEOC's "non-effort" and the futility of further attempts. ${ }^{174}$

In EEOC v. Bass Pro Outdoor World, $L L C,{ }^{175}$ a federal district court within the Fifth Circuit considered a situation similar to that in Bloomberg, but reached a different conclusion. Like the parties in Bloomberg, the parties in Bass Pro engaged in months of discussions but were millions of dollars apart during conciliation. ${ }^{176}$ As in Bloomberg, the employer sought information that the EEOC did not provide. ${ }^{177}$ As part of the three-part inquiry, the court considered whether the EEOC

164. Id. at 639 (citing EEOC v. Johnson \& Higgins, Inc., 91 F.3d 1529, 1535 (2d Cir. 1996)).

165. Id. at 640 .

166. Id. at 638 .

167. Bloomberg $I I, 751$ F. Supp. $2 \mathrm{~d}$ at 640.

168. Id. at 641 .

169. Id. at 641 .

170. Id.

171. Id.

172. Bloomberg $I I, 751$ F. Supp. $2 \mathrm{~d}$ at 641 .

173. Id.

174. Id. at 643.

175. EEOC v. Bass Pro Outdoor World, LLC, 1 F. Supp. 3d 647 (S.D. Tex. 2014).

176. Id. at 651 .

177. Id. 
responded reasonably and flexibly to the employer's reasonable requests. ${ }^{178}$ The court noted that "conciliation requires outlining the basis of the charge," but this showing of evidence "does not require a minitrial," and the EEOC need not reveal all of its evidence. ${ }^{179}$ Unlike the court in Bloomberg, the court refused to dismiss the case, finding that a stay to allow for additional negotiations was a more appropriate remedy. ${ }^{180}$

The Bass Pro court stated at the outset of its decision that it was "uneasy" with its role in evaluating whether the EEOC, an agency "armed with enormous discretion ... undertook settlement discussions in good faith." 181 Furthermore, the court was clearly impressed by the reasoning of the Seventh Circuit in Mach Mining, finding that the decision offered "valuable insights," even though it was "clearly somewhat at odds with binding Fifth Circuit precedent."182 The court agreed with the Seventh Circuit's fears that employers may strategically seek dismissal by asserting failure to conciliate as a defense, despite the low risk of the EEOC abandoning or abusing the conciliation process. ${ }^{183}$ The district court expressed its belief that the courts should "keep the bar for dismissal high" so that claimants would not be prejudiced by the EEOC's failings. ${ }^{184}$ Dismissal, the court noted, should be reserved for "only the truly egregious case" ${ }^{\text {"185 }}$ where the EEOC's conduct was grossly arbitrary and unreasonable. ${ }^{186}$

The courts in Bloomberg and Bass Pro reached different conclusions even though the facts were similar, and both courts employed the more stringent standard of review. Arguably, Bloomberg presented the "truly egregious" case that the court referenced in Bass Pro. Nevertheless, the court in Bass Pro expressed unease with Fifth Circuit precedent that allows for questioning the EEOC's discretion in the conciliation process and admiration for the Seventh Circuit's reasoning in Mach Mining. The court was particularly reluctant to

178. Id. at 653 (citing EEOC v. Agro Distrib., LLC, 555 F.3d 462, 468 (5th Cir. 2009)); EEOC v. Klingler Electric Corp., 636 F.2d 104, 107 (5th Cir. Unit A Feb. 1981) (per curiam) (citing Marshall Sun Oil Co. (Del.), 605 F.2d 1331, 1335-39 (5th Cir. 1979)).

179. Bass Pro, 1 F. Supp. 3d at 653.

180. Id. at 671 .

181. Id. at 650 .

182. Id. at 669 (citing EEOC v. Mach Mining, LLC, 738 F.3d 171 (7th Cir. 2013), cert. granted, 134 S. Ct. 2872 (June 30, 2014) (No. 13-1019)).

183. Id. at 669,670 .

184. Bass Pro, 1 F. Supp. 3d at $670,671$.

185. Id. at 671 .

186. Id. at 673. The court denied Bass Pro's subsequent renewed motion for summary judgment regarding the adequacy of the EEOC's pre-suit obligations. EEOC v. Bass Pro Outdoor World, LLC, 35 F. Supp. 3d 836, 865 (S.D. Tex. 2014). 
dismiss claims rather than allowing additional time for conciliation. These cases demonstrate that a standard based on the reasonableness and flexibility of the EEOC's responses is highly subjective.

\section{Good Faith Standards's Inconsistency with an Informal and Confidential Conciliation Process}

Despite the different levels of scrutiny applied under the discretionary and more stringent standards, some general rules common to both approaches emerge. Under both standards, courts have found that the EEOC does not act in good faith if it prematurely ends conciliation efforts. ${ }^{187}$ Also under both standards, courts have found that if the employer refuses to conciliate or cooperate with requests from the EEOC, the EEOC does not need to do more to satisfy its conciliation duty prior to filing suit. ${ }^{188}$

The cases suggest that it is not only the standard the court uses to assess the EEOC's efforts that impacts outcome, but also the facts of the case. Courts that use the more deferential standard of judicial review attempt to respect the deference accorded to the agency as well as the confidentiality requirement. Nevertheless, the facts of the case and the extent of the negotiations are more likely to dictate the scope of a court's inquiry. If the employer has simply refused the EEOC's invitation to conciliate, it is easy to conclude that the EEOC has fulfilled its statutory duty by "endeavoring" to resolve the dispute before filing suit. If, however, the negotiations have been prolonged or volatile, a court will most likely be influenced by the parties' differing accounts of both the process and substance of the negotiations.

Courts that follow the more stringent approach in reviewing conciliation efforts stray far from the intentions of Title VII. Although some cases indicate that the EEOC may have been aggressive in its negotiating tactics, there is nothing in the statute that prohibits such conduct. In fact, the statute's insistence on informality and confidentiality suggests that courts should not interfere. Congress amended Title VII because it recognized that conciliation was not always possible. The Supreme Court recognized that the EEOC has discretion to determine when to settle and when to file suit. In Occidental Life, the Court stated, "the EEOC does not function simply as a vehicle for conducting litigation on behalf of private parties; it is a federal

187. See EEOC v. Asplundh Tree Expert Co., 340 F.3d 1256, 1260 (11th Cir. 2003); EEOC v. Zia Co., 582 F.2d 527, 533, 543 (10th Cir. 1978).

188. See EEOC v. Johnson \& Higgins, Inc., 91 F.3d 1529, 1535 (2d Cir. 1996); EEOC v. Keco Indus., Inc., 748 F.2d 1097, 1100, 1101-02 (6th Cir. 1984); EEOC v. Radiator Specialty Co., 610 F.2d 178, 183 (4th Cir. 1979). 
administrative agency charged with the responsibility of investigating claims of employment and settling disputes, if possible, in an informal, noncoercive fashion." ${ }^{89}$ This statement not only underscores the discretion that the EEOC has throughout the process but also recognizes that "informal, noncoercive" settlements are not always possible.

\section{JUdiCIAL REVIEW OF THE EEOC'S PRE-SUIT DUTIES REGARDING UNIDENTIFIED AGGRIEVED INDIVIDUALS IN $§ 706$ CLAIMS}

Some of the most contentious cases regarding the duty to conciliate involve suits brought on behalf of one or more identified individuals and unidentified "similarly situated individuals." 190 While courts generally recognize that there must be congruence between the scope of the EEOC's investigation and its lawsuit, they are divided on whether the EEOC can bring a $\S 706$ claim on behalf of individuals not identified before a suit is filed. The Seventh Circuit's decision does not address specifically the extent to which the EEOC must identify and attempt conciliation for each aggrieved individual. This question, however, is central to the discussion of judicial review of conciliation efforts, as the EEOC is likely to pursue cases involving systemic discrimination in light of its stated priorities. ${ }^{191}$ Even after the Supreme Court's decision in Mach Mining, the question remains: does the EEOC have to assert that it attempted to conciliate claims for each aggrieved individual or are its efforts satisfied by conciliation for some named individuals and other similarly situated individuals? ${ }^{192}$

Systemic discrimination cases may be brought under either $\S 706^{193}$ or $\S 707^{194}$ of Title VII. Under $\S 707$, the EEOC brings a claim alleging a pattern or practice of systemic discrimination based largely on statistical information. ${ }^{195}$ In cases brought under $\S 707$, the EEOC does not need to identify specific members of the class aggrieved by

189. Occidental Life Ins. Co. of Cal. v. EEOC, 432 U.S. 355, 368 (1977).

190. See discussion supra at Part III.C. The Bloomberg and Bass Pro cases both involved unidentified aggrieved individuals.

191. See supra note 31.

192. Arguably, the U.S. Supreme Court's reference to the EEOC's limited duty to specify "which employees (or what class of employees) have suffered as a result" of the employer's alleged discriminatory practice indicates that the Court may not require evidence of efforts to conciliate each individual claim. Mach Mining, LLC v. EEOC, 135 S. Ct. $1645,1656(2015)$.

193. 42 U.S.C. $\$ 2000 \mathrm{e}-5(\mathrm{f})(1)$.

194. Id. $\S 2000 \mathrm{e}-6(\mathrm{e})$.

195. See Robinson v. Metro-North Commuter R.R., 267 F.3d 147, 158 (2d Cir. 2001). 
discriminatory practices and only injunctive remedies are allowed. ${ }^{196}$ Section 706(f)(1) of Title VII authorizes the EEOC to seek relief on behalf of an individual or a class of individuals. ${ }^{197}$ In General Telephone Co. of the Northwest v. EEOC, ${ }^{198}$ the Supreme Court made it clear that this class of aggrieved individuals is not subject to Federal Rule of Civil Procedure 23, which contains strict rules about whether or not parties may proceed as a class. ${ }^{199}$ Concluding that Rule 23 has no impact on such suits pursued by the EEOC, the Court stated that "the EEOC is not merely a proxy for the victims of discrimination" but acts "to vindicate the public interest in preventing employment discrimination." 200

In bringing systemic discrimination cases, the EEOC may allege claims under both $\S 706$ and $\S 707$ so that it can seek monetary damages as well as injunctive relief. ${ }^{201}$ In such cases, employers are concerned with finding out who is in the class of aggrieved individuals, how large the class might be, and the amount of damages each individual might be seeking. Employers have asserted a failure to conciliate defense when the EEOC has not identified specific aggrieved individuals until after it has filed suit. ${ }^{202}$

Two distinct approaches to these suits have emerged. Some courts have found that the EEOC must conciliate the claims of each aggrieved individual before filing suit. ${ }^{203}$ Other courts, according broader discretion to the EEOC, have found that appropriate notice of the type of

196. See Arizona ex rel. Goddard v. Geo Grp., Inc., No. CV 10-1995-PHX-SRB, 2012 WL 8667598, at *6-8 (D. Ariz. Apr. 17, 2012) (discussing differences between $\S \S$ 706 and 707 cases and remedies).

197. 42 U.S.C. $\$ 2000 \mathrm{e}-5(f)(1)$.

198. Gen. Tel. Co. of the Nw. v. EEOC, 446 U.S. 318 (1980).

199. Id. at 326. Federal Rule of Civil Procedure 23 states, in pertinent part: One or more members of a class may sue or be sued as representative parties on behalf of all members only if:

(1) the class is so numerous that joinder of all members is impracticable,

(2) there are questions of law or fact common to the class,

(3) the claims or defenses of the representative parties are typical of the claims or defenses of the class; and

(4) the representative parties will fairly and adequately protect the interests of the class.

FED. R. CIV. P. 23(a).

200. Gen. Tel., 446 U.S. at 326.

201. See Jason R. Bent, Systemic Harassment, 77 TenN. L. REv. 151, 193 (2009). Cases such as EEOC v. Bass Pro include $\S \S 706$ and 707 claims.

202. See, e.g., EEOC v. Swissport Fueling, Inc., 916 F. Supp. 2d 1005, 1015 (D. Ariz. 2013) (noting that EEOC began with 17 charging parties and subsequently sought to add nine claimants and then an additional 12).

203. See EEOC v. Bloomberg (Bloomberg IV), 967 F. Supp. 2d 802, 810 (S.D.N.Y. 2013); EEOC v. CRST Van Expedited Inc., 679 F.3d 657, 674 (8th Cir. 2012). 
claims involved is sufficient ${ }^{204}$ and that additional time for conciliation is a more appropriate remedy than dismissal. ${ }^{205}$

\section{A. Conciliation for Each Aggrieved Individual.}

In EEOC v. CRST Van Expedited, Inc., ${ }^{206}$ the Court of Appeals for the Eighth Circuit concluded that the EEOC did not fulfill its pre-suit obligations because it failed to attempt conciliation regarding each victim subsequently named in its lawsuit. ${ }^{207}$ The case was based on complaints of severe and pervasive sexual harassment by female drivers in CRST's New Driver Training Program. ${ }^{208}$ The EEOC notified CRST that it had reasonable cause to believe that a class of female employees had suffered sexual harassment, and the EEOC offered to conciliate; CRST replied that conciliation on a class basis would be futile if CRST did not know the identities of the alleged victims. ${ }^{209}$ After the EEOC filed suit in its own name, seeking relief for the charging party "and a class of similarly situated female employees," 210 the district court and the employer repeatedly asked the EEOC to identify the names of the other aggrieved women. $^{211}$ When the EEOC identified the individuals, CRST sought to dismiss 67 women from the suit because the EEOC had not identified these women during its pre-suit investigation and had not sought to conciliate the charges with regard to these particular women. ${ }^{212}$

Emphasizing that Title VII seeks administrative rather than judicial resolution of disputes, the court found that the EEOC deprived the employer of a meaningful opportunity to conciliate because it did not provide the names of all class members and could not estimate the size of the class prior to filing suit. ${ }^{213}$ The court drew a distinction between facts gathered during the EEOC's pre-suit investigation and those gathered during the discovery phase of a subsequently filed lawsuit. ${ }^{214}$ According to the court, the EEOC may not use the discovery process "as a fishing

204. See, e.g., Serrano v. Cintas, 699 F.3d 884, 890, 904 (6th Cir. 2012), cert. denied, 134 S. Ct. 92 (2013); EEOC v. Bruno's Rest., 13 F.3d 285, 289 (9th Cir. 1993).

205. EEOC v. Bass Pro Outdoor World, LLC, 35 F. Supp. 3d 836, 860 (S.D. Tex. 2014).

206. EEOC v. CRST Van Expedited, Inc., 679 F.3d 657 (8th Cir. 2012).

207. Id. at 677 .

208. Id. at 665 .

209. Id. at 667-68.

210. See id. at 668 .

211. See CRST Van, 679 F.3d at 669 (noting that for nearly two years after the EEOC filed suit it "did not identify the women comprising the putative class despite the district court's and CRST's repeated requests to do so"').

212. See id. at 673-74.

213. Id. at 676 .

214. Id. at 675 . 
expedition to uncover more violations." 15 Finding that "the EEOC wholly failed to satisfy its statutory pre-suit obligations as to these 67 women," the court upheld the district court's dismissal of the EEOC's suit. $^{216}$

In EEOC v. Bloomberg (Bloomberg IV), ${ }^{217}$ the U.S. District Court for the Southern District of New York specifically adopted the court's reasoning in $C R S T .^{218}$ The court concluded that when the EEOC gave Bloomberg notice that it was pursuing claims on a class-wide basis, this notice was not sufficient to satisfy its duty to conciliate each individual claim. $^{219}$ The court recognized that dismissal was a harsh remedy and that some of the meritorious claims would "never see the inside of a courtroom." 220 Nevertheless, the court found that in failing to conciliate the individual claims, the EEOC had "completely abdicate[d] its role in the administrative process." 221

At least one court within the Ninth Circuit has come close to adopting the rule articulated in CRST. In EEOC v. Geo Group, ${ }^{222}$ the court dismissed 15 aggrieved individuals from the EEOC's suit on the grounds that the EEOC did not fulfill its pre-suit conciliation duties. ${ }^{223}$ The EEOC alleged that male managers sexually harassed numerous female employees at its prison facilities. ${ }^{224}$ Although the parties engaged in extensive negotiations, the court found that the employer did not have a meaningful opportunity to engage in conciliation with regard to these 15 women because the EEOC did not identify them or provide information on damages they might have suffered. ${ }^{225}$ The court stated that "[i]nformation on who the aggrieved individuals are and the amount of damages being sought on their behalf is precisely what a reasonable conciliation effort should provide." 226 This decision has been appealed to the Ninth Circuit. ${ }^{227}$

215. Id. at 676 (citing EEOC v. Dillard's Inc., No. 08-CV-1780-IEG (PCL), 2011 WL 2784516, at*7 (S.D. Cal. July 14, 2011).

216. CRST Van, 679 F.3d at 677 .

217. EEOC v. Bloomberg (Bloomberg IV), 967 F. Supp. 2d 802 (S.D.N.Y. 2013).

218. Id. at 815 .

219. Id. at 814 .

220. Id. at 816 .

221. Id.

222. Arizona ex rel. Goddard v. Geo Grp., Inc., No. CV 10-1995-PHX-SRB, 2012 WL 8667598 (D. Ariz. Apr. 17, 2012), appeal docketed sub nom. EEOC v. Geo Grp., Inc., No. 13-16292 (9th Cir. Mar. 7, 2014).

223. Id. at $* 15$.

224. Id. at $* 4-5$.

225. Id. at $* 13-14$.

226. Id. at $* 13$. The court granted a stay allowing additional time for conciliation regarding five individuals because the plaintiffs "may have had these individuals in mind during conciliation proceedings." Id. at * 15 . The case settled with regard to the claims 
The Ninth Circuit's decision in Geo Group will resolve substantial disagreement among the lower courts within the circuit. Some courts have agreed substantially with the CRST approach, maintaining that when the EEOC does not identify the aggrieved individuals, the employer faces "a moving target of liability throughout the conciliation process." 228 This approach favors dismissing claims of unidentified individuals rather than "improperly reward[ing]" the EEOC with additional time for conciliation. ${ }^{229}$ In other district court cases within the circuit, courts have stated that the Ninth Circuit would not go as far as the Eighth Circuit did in CRST. ${ }^{230}$ Several courts recognized that the EEOC is not required to identify every potential class member provided the EEOC gives the employer reasonable notice of the scope of its claim. $^{231}$ One court stated specifically that aggrieved individuals may "piggyback" on charges filed by a claimant as long as the employer has sufficient notice that the EEOC intends to seek remedies for similarly situated employees. ${ }^{232}$

\section{B. Adequate Notice of Class Claims}

Several courts have disagreed pointedly with the Eighth Circuit's $C R S T$ decision. In fact, the decision provoked a vigorous dissent. While the majority chastised the EEOC for its failure to investigate and conciliate individual claims, the dissent found that a requirement for such investigations and conciliation put "unprecedented obligations on the EEOC," and "reward[ed] [the defendant employer] for withholding information from the Commission."233 The dissent emphasized that the EEOC had put the employer on notice that it was investigating a class of

of some of the women shortly after trial began. Press Release, U.S. Equal Emp' $t$ Opportunity Comm'n, GEO Group to Pay $\$ 140,000$ To Settle Sexual Harassment Suit Filed by EEOC and ACRD (Apr. 29, 2013), available at http://www.eeoc.gov/eeoc/newsroom/release/4-29-13.cfm.

227. EEOC v. Geo Grp., Inc., No. 13-16292 (9th Cir. Mar. 7, 2014).

228. See EEOC v. Swissport Fueling, Inc., 916 F. Supp. 2d 1005, 1039 (D. Ariz. 2013); see also EEOC v. Am. Samoa Gov't, No. 11-00525 JMS/RLP, 2012 U.S. Dist. LEXIS 144324, at *21 (D. Haw. Oct. 5, 2012) (stating that the EEOC "may not use discovery in the resulting lawsuit as a fishing expedition to uncover more violations").

229. Swissport, 916 F. Supp. 2d at 1040.

230. EEOC v. Evans Fruit Co., 872 F. Supp. 2d 1107, 1110 (E.D. Wash. 2012).

231. EEOC v. Dillard's Inc., No. 08-CV-1780-IEG (PCL), 2011 WL 2784516, at *8 (S.D. Cal. July 14, 2011) (holding that there was insufficient notice to the employer of a nationwide claim but allowing a regional suit to go forward); Evans Fruit, 872 F. Supp. $2 \mathrm{~d}$ at 1110 (finding that the employer had sufficient notice of claims based on a local class).

232. Evans Fruit, 872 F. Supp. 2d at 1112.

233. EEOC v. CRST Van Expedited, Inc., 679 F.3d 657, 695 (8th Cir. 2012) (Murphy, J., concurring in part and dissenting in part). 
women and had requested the company's help in identifying class members. ${ }^{234}$ The EEOC proceeded with suit, according to the dissent, because it was unable to secure the employer's cooperation during the conciliation. ${ }^{235}$ The dissent stated that the Eighth Circuit has required the EEOC to conciliate for each type of Title VII violation alleged by the complainant, but not to conciliate regarding each individual in a class claim. $^{236}$

The majority's position, according to the dissent, is inconsistent with cases in other circuit courts that have held that the "nature and extent" of the EEOC's investigation is beyond the scope of judicial review. ${ }^{237}$ The dissent also concluded that the majority's position is inconsistent with the purpose of Title VII and that it frustrates the goal of the 1972 amendments to strengthen the EEOC's enforcement powers. ${ }^{238}$ The dissent noted that the employer ended the conciliation process and that the EEOC had made substantial efforts to investigate and conciliate prior to filing suit. ${ }^{239}$ According to the dissent, the court should have stayed the case for further conciliation rather than dismiss it. ${ }^{240}$

The Court of Appeals for the Sixth Circuit, in Serrano v. Cintas Corp. ${ }^{241}$ indicated that the EEOC has substantial discretion in determining the scope of a class-wide claim. ${ }^{242}$ Using the deferential good faith standard it articulated in Keco, the court found that the EEOC had provided adequate notice to the employer that it was investigating discrimination on a class-wide basis because it requested relief for "similarly situated qualified female applicants." ${ }^{243}$ In doing so, the court

234. Id. at 696 .

235. Id.

236. Id. (citing EEOC v. Delight Wholesale Co., 973 F.2d 664, 668-69 (8th Cir. 1992)).

237. Id. (citing EEOC v. Keco Indus., Inc. 748 F.2d 1097, 1100-01 (6th Cir. 1984); EEOC v. Rhone-Poulenc, Inc., 876 F.2d 16, 17 (3d Cir. 1989) (noting in ADEA cases that the EEOC need not conciliate on behalf of individual class members); Dinkins v. Charoen Pokphand USA, Inc., 133 F. Supp. 2d 1237, 1245-46 (M.D. Ala. 2001) (noting that "[w]hat matters is that EEOC served [the employer] notice that it was investigating possible discrimination against a class of women" and that the EEOC need not "conciliate each individual's Title VII claim separately")).

238. CRST Van, 679 F.3d at 697 (Murphy, J., concurring in part and dissenting in part) (citing Gen. Tel. Co. of the Nw., 446 U.S. 318, 325 (1980)).

239. Id.

240. Id.

241. Serrano v. Cintas Corp., 699 F.3d 884 (6th Cir. 2012), cert. denied, 134 S. Ct. 92 (2013).

242. Id. at 904 .

243. Id. (quoting EEOC v. Keco Indus., Inc., 748 F.2d 1097, 1100 (6th Cir. 1984) for the proposition that "the nature and extent of an EEOC investigation into a discrimination claim is a matter within the discretion of th[e] agency"). 
found that the EEOC did not have to conciliate on behalf of the 13 claimants it ultimately named in its suit. ${ }^{244}$

Federal district courts that have disagreed with the CRST outcome have focused on the importance of giving an employer adequate notice of the alleged unlawful conduct or notice of the type of employees aggrieved rather than identifying specific aggrieved individuals. ${ }^{245}$ One court found that "[t]he greater the specificity in describing the alleged unlawful conduct, the less important it becomes to specifically identify aggrieved persons.",246

A federal district court in Texas has had the opportunity to consider extensively the issue involving unidentified individuals in $\S 706$ claims. In EEOC v. Bass Pro Outdoor World, the court rejected the majority's analysis in CRST in favor of the dissent. ${ }^{247}$ The court reasoned that requiring the EEOC to conciliate each individual claim would unduly tax the agency's resources. ${ }^{248}$ Avoiding setting out requirements that the EEOC must always meet, the court found such a "per se rule" arbitrary and inflexible compared to a case-by-case approach. ${ }^{249}$ Nonetheless, the court found that the EEOC should have provided more information to Bass Pro so that Bass Pro would know "how the class was comprised" and have a chance to trim the class by eliminating those who had been hired or whose claims were not timely. ${ }^{250}$ The court was reluctant to tell the EEOC how to conduct the conciliation process, but it indicated that more information should have been forthcoming. ${ }^{251}$

The Bass Pro court emphasized that a stay was the proper remedy rather than dismissal of the lawsuit because it did not find that the

244. Id.

245. See, e.g., EEOC v. Bass Pro Outdoor World, LLC, 1 F. Supp. 3d 647, 655 (S.D. Tex. Mar. 4, 2014) (finding it was more important that the employer have notice about the claims it faced rather than identification of specific individuals); EEOC v. Original Honeybaked Ham Co. of Ga., 918 F. Supp. 2d 1171, 1179-80 (D. Colo. 2013) (rejecting a "categorical interpretation of CRST" and holding that the employer had sufficient notice of the potential aggrieved individuals because the EEOC had provided sufficient detail about the conduct, the alleged perpetrator, and the specific location of the unlawful conduct); EEOC v. Evans Fruit Co., 872 F. Supp. 2d 1107, 1112 (E.D. Wash. 2012) (finding that the employer must have sufficient notice that the EEOC intends to seek remedies for similarly situated employees); EEOC v. Dillard's Inc., No. 08-CV-1780IEG (PCL), 2011 WL 2784516, at *6, *8 (S.D. Cal. July 14, 2011) (stating that the EEOC "is not required to identify every potential class member" but must give the employer reasonable notice of the scope of its claim).

246. Honeybaked Ham, 918 F. Supp. 2d at 1180.

247. Bass Pro, 1 F. Supp. 3d at 665-66.

248. Id. at 665 .

249. Id. at 666 .

250. Id.

251. Id. 
EEOC's premature termination of conciliation was in bad faith. ${ }^{252}$ The court distinguished CRST on the basis that, unlike the EEOC's egregious abdication of duty in CRST, any failure on the EEOC's part in Bass Pro related only to the conciliation stage, and even there, by the midpoint in conciliation, the employer was given an outline to roughly estimate the class size. $^{253}$

On a motion to reconsider its decision, the court noted the ambiguity of the language in $\S 706$, which states that the EEOC will use $\S 706$ to respond to charges "filed by or on behalf of a person claiming to be aggrieved, or by a member of the Commission." 254 The court found that the statute does not make it clear whether the EEOC may pursue claims on behalf of individuals not identified during the investigation. ${ }^{255}$ While taking note that the Supreme Court referred to "a group of aggrieved individuals" in General Telephone, the court found that Bass Pro involved some individuals who were identified and others who were not identified. ${ }^{256}$ The court was also persuaded that General Telephone implied that when the EEOC brought suit under $\S 706$, it was to have all of the same rights as private litigants. ${ }^{257}$ The court concluded that "if private litigants can bring a Rule 23 class action to vindicate the rights of unnamed class members, it follows that the EEOC should be able to do likewise, uninhibited by $\S 706$ 's investigation requirement." 258

In Bass Pro, the court stated that a "growing number of district courts ... come fairly close to making explicit that individuals on whose behalf the EEOC intends to bring $\S 706$ suits must have the merits of

252. Bass Pro, 1 F. Supp. 3d at 667.

253. Id. at $668-69$.

254. EEOC v. Bass Pro Outdoor World, LLC, 35 F. Supp. 3d 836, 861 (S.D. Tex. 2014). This Article does not address the issue of whether the EEOC may, in a lawsuit initiated by it under $\S 706$, rely on the standard of proof set forth by the Supreme Court in Franks v. Bowman Transportation Co., 424 U.S. 747, 772 (1976), and International Board of Teamsters v. United States, 431 U.S. 324, 360 (1977). The employer maintained that the EEOC must use the McDonnell Douglas burden-shifting framework in cases brought under $\S 706$. Bass Pro, 35 F. Supp. 3d at 845. The Bass Pro court held that the EEOC may use the Franks and Teamsters approaches because the Supreme Court has indicated that plaintiffs may use a flexible approach to proving Title VII violations. Id. at 847. The court noted that courts of appeal have allowed the EEOC to use the Teamsters framework in $\S 706$ suits. Id. at 850 (citing Jefferson v. Ingersoll Int'l, Inc., 195 F.3d 894, 899 (7th Cir. 1999); EEOC v. Am. Nat'l Bank, 652 F.2d 1176, 1188 (4th Cir. 1981); EEOC v. Monarch Mach. Tool Co., 737 F.2d 1444, 1449 n.3 (6th Cir. 1980)).

255. Bass Pro, 35 F. Supp. 3d at 861.

256. Id.

257. Id. at 862 .

258. Id. (internal citation omitted) (citing Franks, 424 U.S. at 748). 
their individual claims investigated."259 Nevertheless, the court denied the employer's motion for summary judgment as it was not convinced that the EEOC was barred from bringing claims on behalf of unidentified victims. ${ }^{260}$

\section{IMPACT OF THE SUPREME COURT'S DECISION: A NEW LANDSCAPE FOR EMPLOYERS AND EMPLOYEES}

Employers and the EEOC face a new landscape after the Court's decision in Mach Mining. In 2012, the Eighth Circuit's CRST decision, requiring the EEOC to conciliate for each individual in a pattern or practice suit, was considered a stunning victory for employers. Attorneys maintained that the decision provided "yet another powerful broad-side to attack the EEOC's systemic litigation tactics." ${ }^{261}$ In 2013, the Seventh Circuit's decision in Mach Mining was hailed as a "landmark" victory for the EEOC. ${ }^{262}$ According to the EEOC, the decision " carefully applied the letter of the law ... in a way that promotes Title VII's goals, protects victims of discrimination, and preserves the EEOC's critical law-enforcement prerogatives."263 In choosing between these two extremes, the Supreme Court chose to follow the direction of its previous decisions, which favor the EEOC's discretion and authority to pursue suits that serve the public interest.

\section{A. Resolution of the Merits and the EEOC's Discretion To Bring Suit}

The Supreme Court addressed issues most similar to the judicial review of the EEOC's conciliation efforts in EEOC $v$. Shell Oil. ${ }^{264}$ The decision demonstrates that the Court keeps the prevention of systemic discrimination at the forefront of its analysis and discourages arguments that result in distractions and delays in resolving the merits of Title VII claims. In addressing a challenge to the sufficiency of a procedural

259. Id. at 864-65 (citing EEOC v. CRST Van Expedited, Inc., No. 07-CV-95-LRR, 2009 WL 2524402, at *16 (N.D. Iowa Aug. 13, 2009); EEOC v. Bloomberg L.P. (Bloomberg IV), 967 F. Supp. 2d 802, 814 (S.D.N.Y. 2013)).

260. Bass Pro, 35 F. Supp. 3d at 865.

261. Gerald L. Maatman Jr. \& Howard M. Wexler, Time to Pay Up! EEOC Ordered To Pay \$4.694 Million in Fees and Costs for Pursuing "Unreasonable" and "Groundless" Claims, SEYFARTH SHAw (Aug. 3, 2013), http://www.workplaceclassaction.com/2013/08/time-to-pay-up-eeoc-ordered-to-pay-4694-million-in-fees-and-costs-for-pursuing-unreasonable-and-groundless-claims/.

262. See Press Release, U.S. Equal Emp't Opportunity Comm'n, In Landmark Ruling, Seventh Circuit Holds Employers Cannot Challenge EEOC Conciliation (Dec. 20, 2013), available at http://www1.eeoc.gov//eeoc/newsroom/release/12-2013b.cfm?renderforprint $=1$.

263. See id. (quoting EEOC General Counsel David Lopez).

264. EEOC v. Shell Oil Co., 466 U.S. 54 (1984). 
requirement in Shell Oil, the Court stated, "we must keep in view the more general objectives of Title VII as a whole. The dominant purpose of the Title, of course, is to root out discrimination in employment."265

In Shell Oil, the Supreme Court considered how specific the information in a charge of discrimination must be before the EEOC can seek judicial enforcement of an administrative subpoena. ${ }^{266}$ The employer refused to disclose certain records and data requested by the EEOC unless the EEOC gave it more information on the basis of the charges. $^{267}$ When the EEOC issued a subpoena, the employer, seeking to quash it, argued that the EEOC had not complied with $\S 706(\mathrm{~b})$ because it had not given sufficient facts to the employer. ${ }^{268}$ Like Shell Oil, cases alleging failure to conciliate involve arguments related to sufficiency of process.

In Shell Oil, the Court held that the EEOC's compliance with Title VII's notice requirement was "a jurisdictional prerequisite to judicial enforcement of a subpoena issued by the EEOC."269 But the Court refused to expand the requirements beyond those specifically stated in the statute and the EEOC rule. ${ }^{270}$ The statute requires that charges by the EEOC be in writing, under oath, and "in such form as the Commission requires.",271 The EEOC rule requires that "[e]ach charge should contain ... [a] clear and concise statement of the facts, including the pertinent dates, constituting the alleged unlawful employment practices." 272 The employer maintained that the subpoena was unenforceable because the EEOC did not provide sufficient facts in its charge to satisfy the requirements of Title VII. ${ }^{273}$ The Court concluded that the charge provided the information required by the statute and the EEOC's rule and refused to read those requirements to require additional information. $^{274}$

The Court was concerned that challenges to the sufficiency of the charge would lead to delays, including litigation and appeals about a procedural issue that would have little to do with the merits of the case. The Court stated,

265. Id. at 77 .

266. Id. at 56 .

267. Id. at 58 .

268. Id. at 59 .

269. Shell Oil, 466 U.S. at 65.

270. Id. at 79 ("Respondent asks us to read the statute to require the EEOC to supplement notification... with a summary of the statistical data on which the Commissioner's allegations are founded. We decline the invitation.").

271. Id. at 63 (quoting 42 U.S.C. $\S 2000 \mathrm{e}-5$ (b) (2012)).

272. Id. at 67 (alterations in original) (quoting 29 C.F.R. § 1601.12 (1983)).

273. Id. at 59 .

274. Shell Oil, 466 U.S. at $81-82$. 
The imposition on the EEOC of a duty to reveal the information that precipitated the charge would enable a recalcitrant employer, in a subpoena enforcement action, to challenge the adequacy of the Commission's disclosures and to appeal an adverse ruling by the district court on that issue. The net effect would be to hamper significantly the Commission's ability to investigate expeditiously claims of systemic discrimination. ${ }^{275}$

The Court recognized that employers could use the argument that the charge was insufficient as "a potent weapon" to delay EEOC investigations. ${ }^{276}$ The Court stated that "[a]ny marginal advantage, in terms of facilitating voluntary compliance ... would be more than offset by the concomitant impairment of the ability of the EEOC to identify and eliminate systemic employment discrimination." 277

The Seventh Circuit's Mach Mining decision is based on reasoning similar to that of the Supreme Court in Shell Oil, which the Court could have used as a blueprint to affirm the Seventh Circuit's decision. The Court could have rejected judicial review of conciliation efforts to prevent employers from employing the "potent weapon" argument that conciliation was inadequate. The EEOC has conceded that its duty to conciliate is a judicial prerequisite to filing suit. It fulfills that duty by providing documentation to a court that it initiated conciliation and that, at some point, it determined conciliation failed. The language of the statute requires no more than such facial compliance. ${ }^{278}$ In Mach Mining, the Seventh Circuit expressed concern that time and resources that should have been devoted to resolving the merits of the claims were squandered on litigation and appeals about the sufficiency of conciliation efforts. ${ }^{279}$ This concern echoes that of the Supreme Court in Shell Oil regarding "recalcitrant employers" challenging the sufficiency of the EEOC's procedural steps. ${ }^{280}$

As in the Shell Oil decision, the Seventh Circuit in Mach Mining emphasized that eradicating systemic discrimination must be the central focus of Title VII suits. Moreover, the court asserted that there was "no challenge ... to the facial sufficiency of [the conciliation] documents.",281

275. Id. at 72 .

276. Id.

277. Id. at 81 .

278. See EEOC v. Mach Mining, LLC, 738 F.3d 171, 173 (7th Cir. 2013) (citing Shell Oil, 466 U.S. at 81 (1984)) (noting that there was "no challenge here to the facial sufficiency of these documents" regarding failure to conciliate prior to filing of complaint), cert. granted, 134 S. Ct. 2872 (June 30, 2014) (No. 13-1019).

279. See id. ("The defense has also slowed discovery on the merits of the underlying discriminatory hiring claim.").

280. See Shell Oil, 466 U.S. at 72.

281. Mach Mining, 738 F.3d at 173 (citing Shell Oil, 466 U.S. at 81). 
The proposed defense, according to the Seventh Circuit, allows employers to "avoid liability for unlawful discrimination ... through protracted and ultimately pointless litigation over whether the EEOC tried hard enough to settle." that judicial review of conciliation efforts undermines voluntary compliance and the goals of Title VII. ${ }^{283}$ Not only does the informal process envisioned by Congress give way to "endless disputes over whether the EEOC did enough before going to court," 284 but the goal of eradicating discriminatory practices is overlooked. As the Seventh Circuit observes, employers, especially those who face potentially large and costly claims of discrimination, risk little and gain much in seeking dismissal based on a failure to conciliate. ${ }^{285}$

In Shell Oil, the Court refused to impose burdens on the EEOC that were not reflected in the language of the statute and the EEOC regulation. ${ }^{286}$ Mach Mining suggests that the EEOC should exercise its authority to "issue regulations that provide more detailed content to the conciliation obligation, even while protecting the Commission's discretion to decide what constitutes an acceptable agreement."287

While the EEOC should be guided by its internal policies on conducting quality investigations and conciliation, ${ }^{288}$ promulgating regulations that would be binding would open it to unnecessary attack. The statute's explicit reference to the "informality" of the conciliation process affords considerable flexibility to the EEOC in how the process proceeds. The informality of the conciliation process would be compromised and the EEOC would sacrifice its ability to respond flexibly to the interests of various cases if it committed to binding regulations defining conciliation procedures.

Even in cases where the EEOC might have advanced negotiations by giving more information to the employer, dismissing claims does nothing to advance the goals of Title VII. The Bloomberg case illustrates this point. The court dismissed claims based on a failure to conciliate defense while acknowledging that some of the claims might be "meritorious" but "now will never see the inside of a courtroom.," 289 Nevertheless, the court found dismissal appropriate because it could not

282. Id. at 172 .

283. Id. at $178-80$.

284. Id. at 179 .

285. Id.

286. See Shell Oil, 466 U.S. at $65-66$.

287. See Brief for Petitioner, supra note 4 , at 35 .

288. See Quality Control Plan 2013 Draft Principles, supra note 51; supra notes 5152 and accompanying text.

289. EEOC v. Bloomberg, L.P. (Bloomberg IV), 967 F. Supp. 2d 802, 816 (S.D.N.Y. 2013). 
"promote[] litigation in contravention of Title VII's emphasis on voluntary proceedings and informal conciliation."290 The court's conclusions in Bloomberg are shortsighted as they elevate adherence to unspecified procedures over the goal of addressing unlawful discrimination. Furthermore, the court's fear of promoting litigation ignores the fact that Title VII authorizes the EEOC to bring civil actions-precisely because Congress realized that voluntary compliance was frequently unsuccessful. Thus, courts that follow Bloomberg that would dismiss claims because of a failure to conciliate ignore not only the discretion invested in the EEOC in the conciliation process, but also its authority to bring suit and, most importantly, the overarching goals of Title VII.

The Supreme Court has also emphasized the EEOC's discretion to litigate suits that it believes are in the public's interest, even though the preferred method of resolving Title VII suits is through voluntary conciliation. In EEOC v. Waffle House, ${ }^{291}$ the Court recognized that "once a charge is filed . . the EEOC is in command of the process" and "master of its own case." 292 Moreover, the Court recognized that Title VII "confers on the agency the authority to evaluate the strength of the public interest at stake."293 The Court noted that "it is the public agency's province-not that of the court-to determine whether public resources should be committed to the recovery of victim-specific relief. And if the agency makes that determination, the statutory text unambiguously authorizes it to proceed in a judicial forum. $" 294$

In addressing the conciliation issue, courts have not given adequate consideration to the EEOC's right to pursue cases in the public interest. For example, in Asplundh Tree, the court concluded that the EEOC's decision to file suit "may have been motivated, at least in part, by the fact that conciliation, unlike litigation, is not in the public domain." "295 Whether the EEOC chooses to file suit in high-profile cases or not, the Court's decision in Waffle House suggests that such decisions are clearly within the agency's discretion. ${ }^{296}$

290. Id.

291. EEOC v. Waffle House, Inc., 534 U.S. 279, 291 (2002). The Court considered whether an agreement between an employer and an employee to arbitrate employmentrelated disputes bars the EEOC from pursuing victim-specific judicial relief. Id. at 28485. The Court held that it did not. Id. at 285 . Three justices dissented. Id. at 298 (Thomas, J., Rehnquist, C.J., and Scalia, J., dissenting).

292. Id. at 291 (majority opinion).

293. Id.

294. Id. at 291-92.

295. EEOC v. Asplundh Tree Expert Co., 340 F.3d 1256, 1261 n.3 (11th Cir. 2003).

296. See, e.g., Brief of Amici Curiae Retail Litigation Center, Inc., Chamber of Commerce of the United States of America, and National Federation of Independent 
The EEOC's discretion to pursue cases that advance the public interest also weighs against the argument that it must attempt conciliation for each aggrieved individual before filing suit. Preserving the EEOC's ability to pursue cases involving systemic discrimination comes at an important time. Several scholars have noted that the EEOC has a greater role to play in preventing systemic discrimination since the Supreme Court's decision in Wal-Mart v. Dukes. ${ }^{297}$ In Wal-Mart, the Court found that claims for backpay in a Title VII gender discrimination class action suit could not be certified if the victims "would be entitled to an individualized award of monetary damages."298 Thus, assuming, as many scholars have, that the Supreme Court's decision in Wal-Mart has made class action cases under Title VII much more difficult to pursue, ${ }^{299}$ the EEOC's role in addressing systemic discrimination is more important than ever. ${ }^{300}$ Without the requirements of Rule 23, the EEOC has the ability to address discrimination using a "class-action-like mechanism."301 Allowing the EEOC to bring claims under $\S 706$ on behalf of unidentified individuals improves the chances of deterring systemic discrimination.

\section{B. The High Costs of Judicial Review and Minimal Benefits to Employers}

Much of the battle regarding review of conciliation efforts centers on the litigation strategy of employers and the EEOC. The statutory scheme favors erring on the side of resolving meritorious claims, especially when there are sufficient checks on overzealous EEOC conduct. With its emphasis on the "net effect" of conciliation and litigation under Title VII, the various strategies that the EEOC and employers pursue in the process should not concern the Court. ${ }^{302}$

Business Small Business Legal Center in Support of Petitioners at 6, EEOC v. Mach Mining, LLC, 738 F.3d 171 (7th Cir. 2013) 134 S. Ct. 2872, cert. granted, (June 30, 2014) (No. 13-1019) (stating that the EEOC may choose not to settle privately because of the "allure of filing a high-profile case").

297. Wal-Mart Stores, Inc. v. Dukes, 131 S. Ct. 2541 (2011); see Melissa Hart, Civil Right and Systemic Wrongs, 32 BERKELEY J. EMP. \& LAB. L. 455, 475 (2011) (suggesting a greater reliance on EEOC enforcement for cases involving systemic discrimination post Wal-Mart); Joseph A. Seiner, Weathering Wal-Mart, 89 NOTRE DAME L. REV. 1343, $1345,1352-56(2014)$.

298. Wal-Mart, $131 \mathrm{~S}$. Ct. at 2557.

299. See Seiner, supra note 297 , at $1350 \&$ n.61 (collecting articles in which scholars "denounced the case as one that undermines the rights of workplace discrimination victims").

300. See id. at 1345, 1352-56; Hart, supra note 297 , at 475-76.

301. See Seiner, supra note 297, at 1345, 1356.

302. See EEOC v. Shell Oil Co., 466 U.S. 54, 72 (1984). 
If the Supreme Court finds that judicial review of conciliation efforts is required, the Seventh Circuit's fear that "the employer's incentive to reach an agreement can be outweighed by the incentive to stockpile exhibits for the coming court battle",303 could be realized. Mach Mining and employer groups assert that employers have strong incentives to settle and that no rational employer "would incur with certainty the financial and reputational costs of an EEOC lawsuit in the hopes of subsequently manipulating the conciliation review process., ${ }^{304}$ Nevertheless, it appears that the Seventh Circuit's concern about employers using a failure to conciliate defense has merit. The EEOC maintains in its brief to the Court that "in the circuits that permit judicial review, the effort to 'stockpile exhibits' is already happening." ${ }^{, 305}$ One prominent employment firm, referencing the result in CRST, advises employers to view every communication with the EEOC as an exhibit in future court motions. ${ }^{306}$

Employers' fears that a lack of judicial review will lead the EEOC to "abandon conciliation altogether or misuse it by advancing unrealistic and even extortionate settlement demands" are unfounded. ${ }^{307}$ Despite a few cases that indicated insufficient investigation and a rush to litigate, the risk of the EEOC abusing its right to bring suit is minimal. In addition to the natural constraints provided by limited resources, Title VII provides that courts have discretion to award attorneys' fees to a prevailing defendant. ${ }^{308}$ Interpreting this provision, the Supreme Court stated that fees may be awarded "upon a finding that the plaintiff's action was frivolous, unreasonable, or without foundation, even though not brought in subjective bad faith." ${ }^{309}$ This provision is sufficient to protect employers in the rare case that the EEOC brings an unfounded suit. In $C R S T$, for example, the court awarded the employer $\$ 4.6$ million in attorneys' fees and expenses because the EEOC brought a sexual harassment suit involving approximately 270 allegedly aggrieved

303. See EEOC v. Mach Mining, LLC, 738 F.3d 171, 178 (7th Cir. 2013), cert. granted, 134 S. Ct. 2872 (June 30, 2014) (No. 13-1019).

304. E.g., Brief of Amici Curiae Retail Litigation Center, Inc., supra note 296, at 4.

305. See Brief for the Respondent, supra note 3, at 40.

306. Pro-Actively Addressing and Preparing for EEOC Investigations \& Lawsuits,

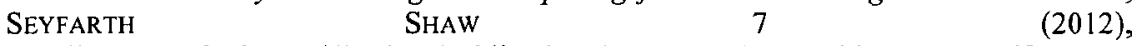
http://www.seyfarth.com/dir_docs/publications/eeoccountdownwebinar72512.pdf.

307. See Mach Mining, $7 \overrightarrow{3} 8$ F.3d at 179.

308. Section $706(\mathrm{k})$ of Title VII provides: "In any action or proceeding under this subchapter the court, in its discretion, may allow the prevailing party . . . a reasonable attorney's fee ...." 42 U.S.C. $§ 2000 \mathrm{e}-5(\mathrm{k})(2012)$.

309. Christiansburg Garment Co. v. EEOC, 434 U.S. 412, 421 (1978). 
individuals with little investigation. ${ }^{310}$ All claims were dismissed by the district court or withdrawn by the EEOC, with the exception of one claim that settled for $\$ 50,000 .^{311}$ In finding that the EEOC's claim was frivolous, the court noted that the EEOC presented no expert evidence, statistics, or legal authority and its case depended on nothing more than "bald assertions." 312

If the EEOC pursues a Title VII case that a court determines is "frivolous, unreasonable, or without foundation," it will pay the consequences, and employers will at least be reimbursed for the expenses incurred. ${ }^{313}$ Most cases, however, that have alleged a failure to conciliate defense would not be found frivolous or unreasonable. In cases where the employer claims the EEOC imposed too short a period of time for conciliation, arbitrarily terminated conciliation, or provided insufficient information, courts should either accept the EEOC's conclusion that it satisfied its pre-suit duty to conciliate or exercise its discretion to order further conciliation.

\section{CONCLUSION}

Courts currently take divergent views of the EEOC's pre-suit obligations. At one extreme, courts would allow a searching inquiry into the conciliation process, with an emphasis on whether or not the EEOC responded reasonably to the employer's reasonable demands. At the other extreme, one court has stated that courts should require only facial compliance with the conciliation requirement. The Supreme Court chose not to affirm the Seventh Circuit's decision in Mach Mining. However, in stating that courts should not review conciliation efforts, the Seventh Circuit relied primarily on the text of the statute and the thrust of the statutory scheme, both themes that the U.S. Supreme Court echoed in its recent decision in Mach Mining. The Seventh Circuit's approach is supported by Supreme Court decisions suggesting that courts should not undercut the wide discretion that Title VII gives to the EEOC in determining when conciliation will be fruitful and when the public interest is served by filing suit. A decision requiring judicial review could compromise the informality of the process and require the EEOC to guard against employers' strategic use of a failure to conciliate defense. However, the narrow review outlined by the Supreme Court in Mach Mining limited this danger, and the Court's dictated remedy of

310. EEOC v. CRST Van Expedited, Inc., No. 07-CV-95-LRR, 2013 WL 3984478, at

*2, *20 (N.D. Iowa Aug. 1, 2013).

311. Id. at $* 6, * 21$.

312. Id. at *13-14.

313. See Christiansburg, 434 U.S at 421. 
more conciliation rather than dismissal of the claim safeguards against loss of meritorious claims due to procedural bungles.

\section{ADDENDUM}

As this Article went to press, the Supreme Court held, in a unanimous decision, that EEOC efforts to conciliate are subject to judicial review but that the scope of that review is very narrow. ${ }^{314}$ The EEOC, according to the Court, has "extensive discretion to determine the kind and amount of communication with an employer appropriate in any given case." 315 Although the Court rejected the Seventh Circuit's argument in Mach Mining that there is no workable standard of judicial review regarding conciliation efforts, the Court largely endorsed the reasoning of the Seventh Circuit and concluded that a "relatively barebones review" is appropriate. ${ }^{316}$ The Court noted that the Seventh Circuit did in fact subject the EEOC's activities to "a smidgen of review" that entailed the Commission's pleading that it had complied with prelitigation requirements, including its two letters to the employer. ${ }^{317}$ The Court's analysis is consistent with the Seventh Circuit's reasoning in its emphasis on the EEOC's discretion, the importance of preserving confidentiality, and the conclusion that the proper remedy for any flaw in the conciliation process is more conciliation, rather than dismissal of the case. $^{318}$ For these reasons, the Supreme Court's decision is decidedly a victory for the EEOC and employees seeking to hold employers accountable for workplace discrimination. ${ }^{319}$

\section{A. Manageable Judicial Review of Conciliation Efforts}

The Court rejected the Seventh Circuit's conclusion that Title VII does not require judicial review of conciliation efforts because of "the

314. Mach Mining, LLC v. EEOC, 135 S. Ct. 1645, 1649 (2015).

315. Id.

316. Id. at $1649,1655-56$

317. Id. at $1650-51$ (citing $738 \mathrm{~F} .3 \mathrm{~d} 171$ at 184 ).

318. Id. at $1654-56$.

319. See Kevin McGowan, EEOC Conciliation Subject to Court Scrutiny, But Scope of Review is Limited, Justices Rule, Daily Lab. Rep. (BNA) No. 82, at AA-1 (Apr. 29, 2015) (noting EEOC General Counsel P. David Lopez "called the ruling 'great news' for the agency and discrimination victims [in that] the court rejected the intrusive review proposed by [Mach Mining]"); Jacob Gershman, Legal Experts Weigh in on Supreme Court's EEOC Ruling, WALL ST. J. (Apr. 29, 2015), http://blogs.wsj.com/law/2015/04/29/legal-experts-weigh-in-on-supreme-courts-eeocruling/ (noting employers had "little to cheer" in Supreme Court's Mach Mining decision and quoting law professor that "it's unambiguously a win for the EEOC"). 
strong presumption' favoring judicial review of administrative action.",320 Nothing in Title VII rebuts this presumption, the Court stated. ${ }^{321}$ Moreover, the Court found that the language of Title VII makes conciliation mandatory. ${ }^{322}$ The Court compared the EEOC's prelitigation requirements to the similar requirements placed upon discriminatees, namely that they must file a charge at the EEOC and receive a right to sue letter before proceeding to court. ${ }^{323}$ The Court stated that it did not "doubt the EEOC's trustworthiness, or its fidelity to law," but that Congress recognizes that "legal lapses and violations occur, and especially so when they have no consequence."324

Contrary to the Seventh Circuit's conclusion in Mach Mining, the Court found that there was a "manageable standard" for reviewing conciliation efforts. ${ }^{325}$ The Court provided information about what is required of the EEOC to fulfill its statutory duty "by informal methods of conference, conciliation, and persuasion.,"326 Using dictionary definitions, the Court stated that the terms utilized in the statute indicate "consultation or discussion,' an attempt to 'reconcile' different positions, and a "means of argument, reasoning, or entreaty.",327 In short, the EEOC must inform the employer about the alleged unlawful employment claim and provide the employer an opportunity to discuss and resolve the matter through voluntary compliance. ${ }^{328}$

\section{B. Scope of Judicial Review - "Relatively Barebones"}

In addressing the scope of judicial review of the EEOC's conciliation efforts, the Court rejected the Seventh Circuit's conclusion that courts may limit consideration of conciliation efforts to a facial examination of EEOC documents. ${ }^{329}$ Nevertheless, the standard of review the Court fashioned is more similar to the Seventh Circuit's prescription for minimal review and far from the "more intrusive review" that employers have endorsed and some courts have favored. ${ }^{330}$ The Court concluded that the EEOC's "bookend" documents consisting of an

320. Mach Mining, LLC v. EEOC, 135 S. Ct. 1645, 1651 (2015) (citing Bowen v. Michigan Acad. of Family Physicians, 476 U.S. 667, 670 (1986)).

321. Id. at 1653 .

322. Id. at 1651 .

323. Id. at 1651-52.

324. Id. at 1652-53.

325. Mach Mining, 135 S. Ct. at 1652.

326. Id. at 1652 .

327. Id.

328. Id. at 1652-53.

329. Id. at 1653-54.

330. Mach Mining, 135 S. Ct. at 1653. 
initial letter indicating the EEOC found reasonable cause and would contact the employer about the conciliation process and a final letter stating that conciliation efforts had occurred and failed, were not sufficient to prove that conciliation had occurred. ${ }^{331}$ Judicial review, the Court stated, must "verify" the EEOC's assertion that it tried to conciliate the discrimination claim. ${ }^{332}$ The Court concluded, however that "[a] sworn affidavit from the EEOC stating that... its efforts have failed will usually suffice to show that it has met the conciliation requirement. ${ }^{, 333}$ The EEOC's verification could be challenged by an employer's affidavit stating the EEOC did not provide information about the charge or attempt to discuss voluntary resolution. ${ }^{334}$ A court's review, the Court stated, would be limited to fact-finding about these issues. ${ }^{335}$

The Court specifically rejected the "deep dive" approach to reviewing conciliation efforts that the employer recommended in Mach Mining. ${ }^{336}$ The employer had suggested a "bargaining checklist" that imposed requirements on the EEOC such as disclosing the minimal remedial amount it would accept; refraining from take-it-or-leave offers; and engaging in a process of offer and counteroffer with time to review and respond to each during negotiations. ${ }^{337}$ The Supreme Court refused to impose requirements that are not specified in Title VII. ${ }^{338}$ Like the Seventh Circuit, the Court emphasized the broad discretion given to the EEOC in its conciliation efforts. ${ }^{339}$ The Court made it clear that courts should not review the EEOC's "strategic decisions," "the pace and duration of conciliation efforts," or "the content of its demands for relief., 340

The Supreme Court, like the Seventh Circuit, also recognized the importance of Title VII's confidentiality requirement. ${ }^{341}$ Judicial review of the content of negotiations is prohibited, the Court stated. ${ }^{342}$ The Court noted that confidentiality promotes candor in discussions, thereby increasing the likelihood of an agreement. ${ }^{343}$

331. Id.

332. Id. (emphasis in original).

333. Id. at 1656 .

334. Id.

335. Mach Mining, 135 S. Ct. at 1656.

336. Id. at 1653-54.

337. Id. at $1653-55$.

338. Id. at $1655-56$.

339. Id. at 1656 .

340. Mach Mining, 135 S. Ct. at 1654.

341. Id. at 1655 .

342. Id.

343. Id. 
The Court's analysis is also similar to that of the Seventh Circuit in Mach Mining because it emphasizes the importance of resolving the merits of the claim over the conciliation process. ${ }^{344}$ The Court specifically rejected any similarity between the NLRA's good faith requirements and the conciliation requirements under Title VII. ${ }^{345}$ Where the NLRA has specific rules about the bargaining process, "Title VII ultimately cares about substantive results, while eschewing any reciprocal duties of good-faith negotiation. ${ }^{346}$

The Court concluded that if a court were to find that the EEOC did not fulfill its statutory duty to conciliate, "the appropriate remedy is to order the EEOC to undertake the mandated efforts to obtain voluntary compliance." 347 In other words, the appropriate remedy is to renew conciliation efforts. The Court's decision makes no reference to dismissing cases for failure to conciliate.

\section{Conciliation Issues Resolved and Unresolved}

The Supreme Court's decision resolves some but not all of the issues raised in the lower courts regarding conciliation. The Court stated that conciliation efforts are subject to judicial review and provided some guidance about the scope of judicial review. Although the Court did not specifically adopt or endorse any of the standards followed by the circuit courts of appeal, or use terminology such as "deferential" or "more stringent" in describing its approach to reviewing failure to conciliate claims, its approach is closest to the so-called deferential standard of review. ${ }^{348}$ Consistent with the Supreme Court's decision, lower courts that have used the deferential standard have focused primarily on whether or not the EEOC attempted to communicate with the employer and have steered clear of inquiring into the content of conciliation efforts. $^{349}$ In light of the Supreme Court's decision, however, courts should refrain from using the term "good faith" in connection with the review of conciliation efforts. The Court made it clear not only that Title VII's conciliation process is entirely distinct from the "good faith"

344. Id. at $1655-56$.

345. Mach Mining, 135 S. Ct. 1654.

346. Id.

347. Id. at 1656 .

348. See discussion supra Part III.A

349. See, e.g., EEOC v. Radiator Specialty Co., 610 F.2d 178, 183 (4th Cir. 1979) (conciliation requirement satisfied when employer failed to respond to invitation to conciliate); EEOC v. Keco Indust., Inc., 748 F.2d 1097, 1102 (6th Cir. 1984) (conciliation requirement satisfied when employer rejected conciliation attempt); Serrano v. Cintas Corp., 699 F.3d 884, 904 (6th Cir. 2012), cert. denied, 134 S. Ct. 92 (2013) (same). 
bargaining required in NLRA proceedings, but also that "Title VII . . . eschew[s] any reciprocal duties of good-faith negotiation." 350

The Supreme Court's decision clearly rejects the more stringent standard of review used by several circuit courts of appeal. ${ }^{351}$ This standard employed a three-part inquiry requiring the EEOC to (1) outline to the employer its cause for believing an unlawful discrimination practice had occurred; (2) give the employer a chance to comply voluntarily; and (3) respond in a reasonable and flexible manner to reasonable questions or offers of the employer. ${ }^{352}$ The Supreme Court's decision requires the EEOC to comply with the first and second parts of this standard, but rejects the third, most controversial step. The Seventh Circuit had cautioned that courts should not seek to distinguish between the process and substance of the conciliation because it interfered with the EEOC's discretion as well as the confidentiality that Title VII mandates. ${ }^{353}$ The Supreme Court's decision clarified that courts must respect the broad discretion that Title VII gives to the EEOC regarding conciliation as well as the importance of maintaining confidentiality in the conciliation process. ${ }^{354}$

The Court also made it clear that, if the EEOC fails to fulfill its conciliation obligations, the proper remedy is an order for more conciliation. ${ }^{355}$ With this statement, the Court indicates that dismissing suits for failure to conciliate is not the appropriate remedy. Some lower courts have maintained that claims should be dismissed when the EEOC has not given the employer an opportunity to conciliate. ${ }^{356}$ These cases have often involved situations in which the EEOC has sued on behalf of a class of unidentified aggrieved individuals. In deciding Mach Mining, the Supreme Court did not have the opportunity to address how courts should review conciliation issues involving unidentified aggrieved individuals. The Court's language, however, suggests that it would reject the approach followed by some lower courts that have required the EEOC to conciliate with regard to each aggrieved individual in order to

350. Mach Mining, 135 S. Ct. at 1654.

351. See discussion supra Part III.B.

352. This standard was developed by the court in Marshall v. Sun Oil Co. (Del.), 605 F.2d 1331 (5th Cir. 1979) in a case involving the ADEA and was adopted in Title VII cases in the Fifth, Eleventh, and Second Circuits. See discussion supra Part III.B.

353. EEOC v. Mach Mining, LLC, 738 F.3d 171, 183 (7th Cir. 2013).

354. Mach Mining, 135 S. Ct. at 1654-55.

355. Id. at 1656 ("Should the court find in favor of the employer, the appropriate remedy is to order the EEOC to undertake the mandated efforts to obtain voluntary compliance.").

356. See, e.g., EEOC v. CRST Van Expedited, Inc., 679 F.3d 657 (8th Cir. 2012); EEOC v. Bloomberg (Bloomberg IV), 967 F. Supp. 2d 802 (S.D.N.Y. 2013). 
satisfy its pre-suit obligations. ${ }^{357}$ To fulfill its conciliation duties, the Court stated, the EEOC must provide notice to the employer describing "what the employer has done and which employees (or what class of employees) has suffered as a result." of employees" suggests that the EEOC fulfills its conciliation requirement by notifying the employer of the alleged unlawful conduct and the type of employees aggrieved and opening communication on this basis. Some lower courts have followed this approach, recognizing the EEOC's broad discretion in determining the scope of a class-wide claim. $^{359}$

In the wake of the Supreme Court's decision, employers and employees are posturing to spin the Court's decision in their favor. With some issues resolved about the EEOC's conciliation efforts and the scope of review required, the next frontier is likely to be whether the EEOC has fulfilled its pre-suit obligation to investigate. ${ }^{360}$ Title VII requires the EEOC to notify an employer of the charge of an unlawful employment practice and to "make an investigation thereof." 361

The Court of Appeals for the Second Circuit applied the Supreme Court's reasoning in Mach Mining in a case involving the sufficiency of an EEOC investigation. In EEOC v. Sterling Jewelers Inc., ${ }^{362}$ the EEOC alleged that Sterling, the nation's largest jewelry store chain, discriminated against women by not paying them the same as their male counterparts and by not promoting qualified women. ${ }^{363}$ Sterling moved for summary judgment, maintaining that the EEOC did not conduct a sufficient pre-suit investigation and, therefore, failed to satisfy its statutory duty under Title VII. ${ }^{364}$ The Second Circuit disagreed. The court held that under Title VII, "courts may review whether the EEOC conducted an investigation, but not the sufficiency of an investigation."365 The court noted that the Supreme Court's decision in Mach Mining did not address the scope of EEOC investigations, but

357. See discussion supra at Part IV.A.

358. Mach Mining, 135 S. Ct. at 1651 (emphasis added).

359. See discussion supra at Part IV.B, regarding Serrano v. Cintas Corp., 699 F.3d 884, 904 (6th Cir. 2012), cert. denied, 134 S. Ct. 92 (2013) and EEOC v. Bass Pro Outdoor World, LLC, 1 F. Supp. 3d 647, 665-66 (S.D. Tex. Mar. 4, 2014).

360. See Ben James, EEOC, Sterling Jewelers Spar Over Mach Mining at 2nd Circ., LAw 360 (May 4, 2015), http://www.law360.com/articles/651281/eeoc-sterling-jewelersspar-over-mach-mining-at-2nd-circ.

361. 42 U.S.C. $\S \S 2000 \mathrm{e}-2,2000 \mathrm{e}-3,2000 \mathrm{e}-5(\mathrm{a})$ (2012).

362. EEOC v. Sterling Jewelers Inc., No.14-1782, 2015 U.S. App. LEXIS 15986 (2d Cir. Sept. 9, 2015).

363. Id. at $* 4$.

364. Id. at $* 7$.

365. Id. at $* 3$. 
found that judicial review of an EEOC investigation is similar to judicial review of the conciliation process. ${ }^{366}$ In other words, the court emphasized the limited nature of judicial review of an EEOC investigation. The court relied on the Supreme Court's language that "Title VII ultimately cares about substantive results."

In Mach Mining, as in previous decisions, the Supreme Court has consistently emphasized that eradicating systemic discrimination must be the focus of Title VII suits. Consequently, in reviewing the EEOC's statutory duties under Title VII, lower courts should not impose additional requirements on the EEOC that would detract from the underlying issues of discrimination or lead to dismissal of meritorious claims. 
